بسم الله الرحمن الرحيم

\title{
القيم الأخلاقية
}

\section{وأثرها في تقيقيق الأهن النفسي \\ دراسة من هنظور السنة النبوية \\ الدكثورة \\ فاتن عبد القادر بابكر}

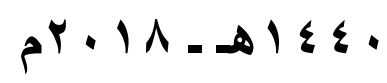


- $\{\diamond \vee \wedge$ - 


\section{ملخص البحث}

يعرف الأمن النفسي كذلك بأنه : الطمأنينة النفسية أو الانفعالية للدى الفرد، وحالة يكون فيها إثباع الحاجات مضمونً وغير معرض للخطر ومحرك للفرد في تحقيق أمنهه ، وهو حاجة من حاجات الفرد، إثباعها يجعله يشعر بالارتياح والاطمئنان ومن خلال شعوره بالانتماء أو تقبل الآخرين له والتحرر من الخوف والألم . ـ في السنة النبويـة، مـا يؤكد أهمية أمن الإنسان في الجماعة التي يعيش فيها، فالأمن على نفس الإنسـان، وعلى سـلامة بذنـه مـن العلل، والأمن على الرزق، هو الأمـن الشامل الأي أوجز الإحاطة به وتعريفه وهو ما تناولته الأحاديث الواردة في هذا الجانب ، وجعلت تحقق هذا الأمن لاى الإنسان بمثابة ملك الانيا بأسرها . ـ إن تنمية القيم الخلقية لدى الإنسان المسلم تعتمد على تكوين الوازع الداخلي في الفرد منذ الطقولة الأولى حيث يؤمن الفرد بالقيم، ويكتسبها ويتثربها ويضيفها إلى إطاره المرجعي للسلوك، ويتم ذلك من خلال التشئة الاجتماعية، وعن طريق التفاعل الاجتمـاعي يتعلم الفرد أن مواقفه يجب أن تتسم بالخلقية وذلك حتى يشارك في حياة المجتمع بفاعلية. 


\section{Research Summary}

Psychological security is also defined as: the psychological or emotional reassurance of the individual, a situation in which satisfaction of the needs is guaranteed and not at risk and the individual's drive to achieve his security, a need of the individual needs, satisfaction makes him feel comfortable and secure and through his sense of belonging or others accept him and freedom from fear And pain.

In the Prophet's Sunnah, which confirms the importance of human security in the community in which he lives. Security of the same person, the integrity of his body from the ills, and security of livelihood, is the comprehensive security which outlined his briefing and definition. Human security is the king of the whole world.

The development of the moral values of a Muslim man depends on the formation of internal intelligence in the individual since the first childhood, where the individual believes in values, and acquires and drinks and adds to the frame of reference of behavior, and this is through socialization, and through social interaction, the individual learns that his positions must be ethical So as to participate in the life of society effectively. 


\section{مقدمة}

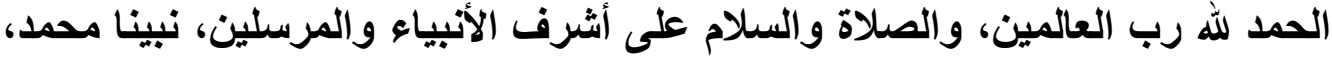

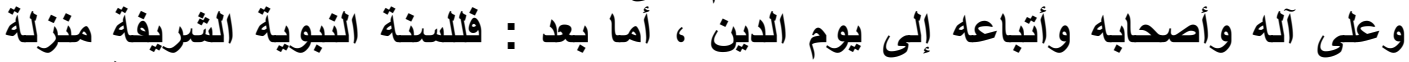

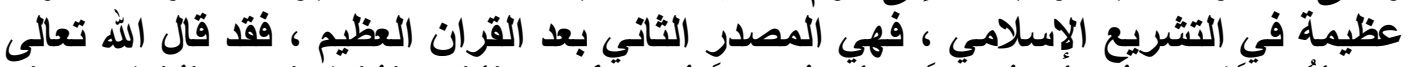

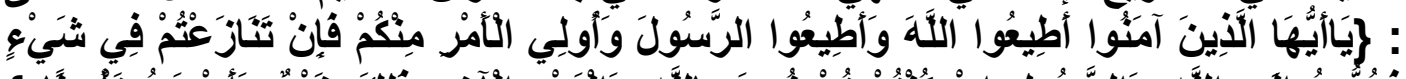

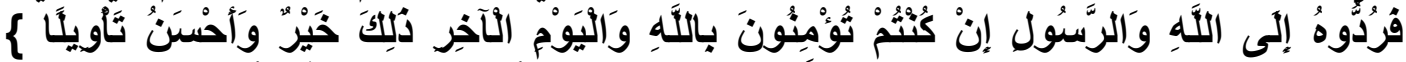

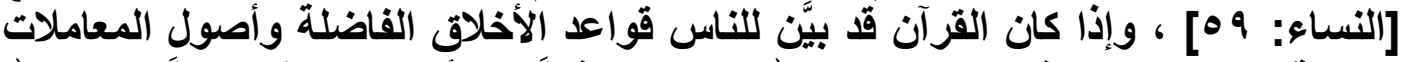

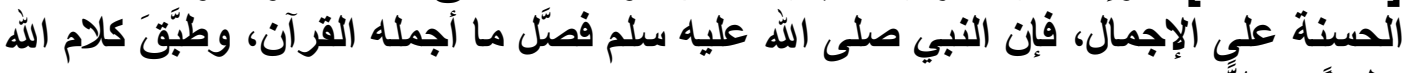

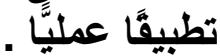

و الأخلاق دليل الإسلام وترجمته العملية ، وكلما كان الإيمان قويا أثمر خلقا قويا ، كما

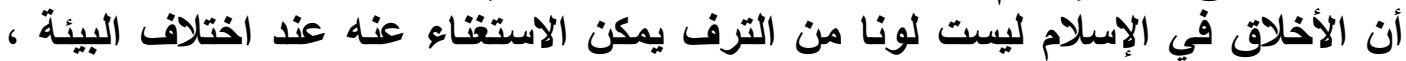

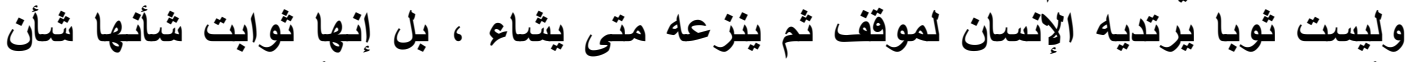

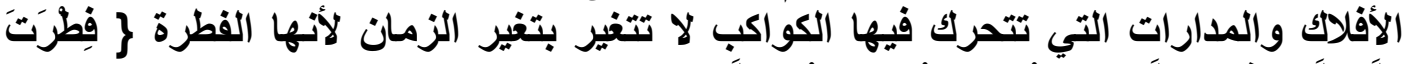

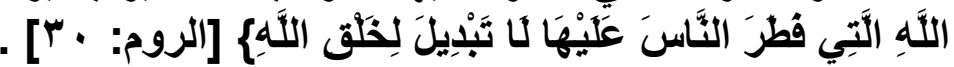

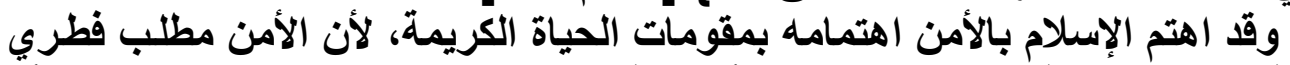

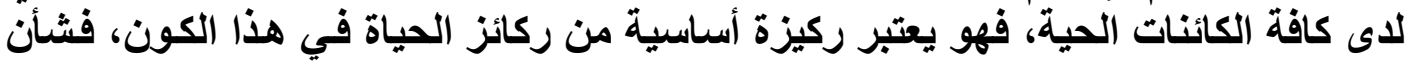

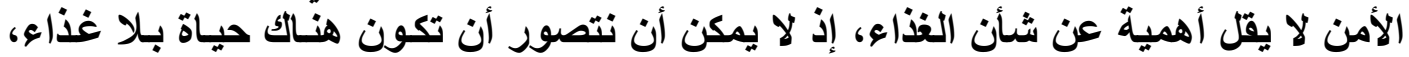

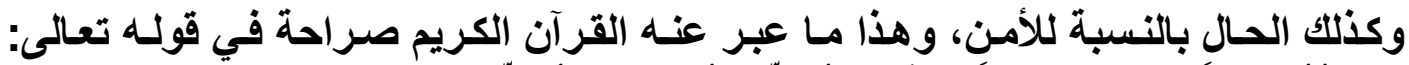

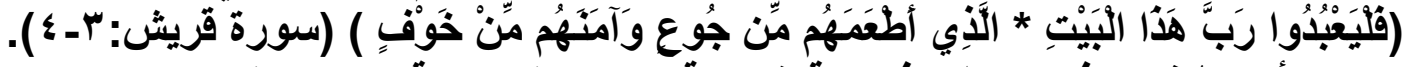

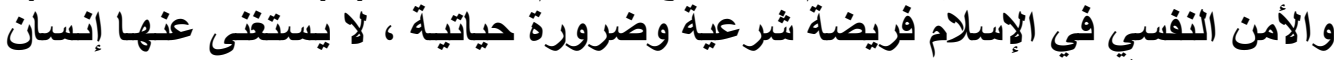

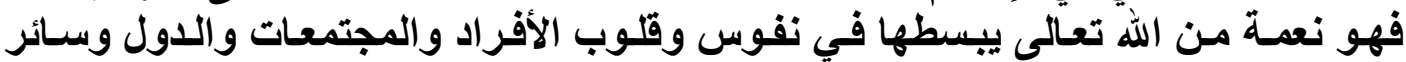

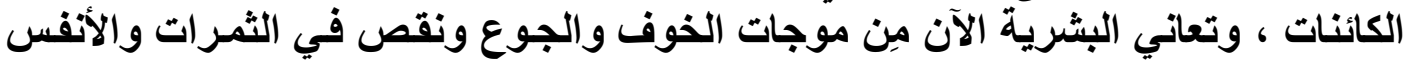

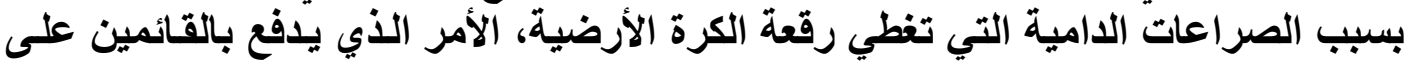

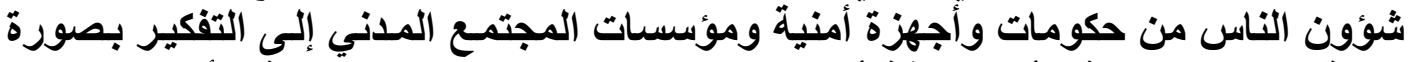

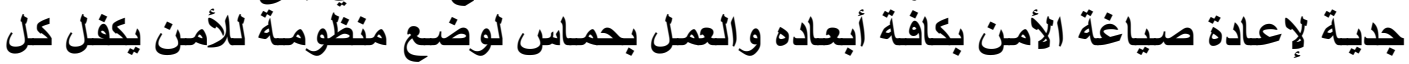

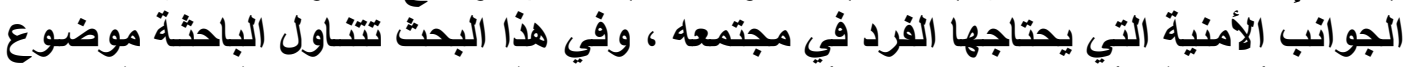

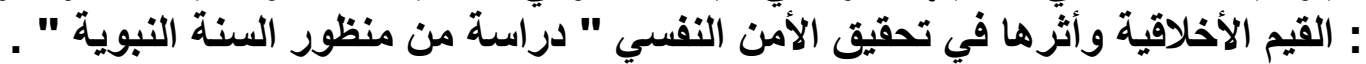

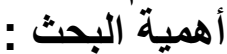

تكمن أهمية البحث في النقاط التالية :

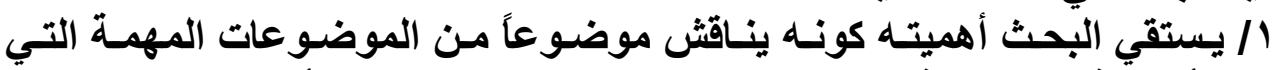

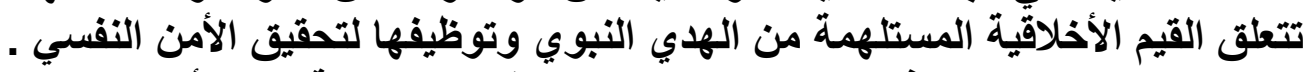

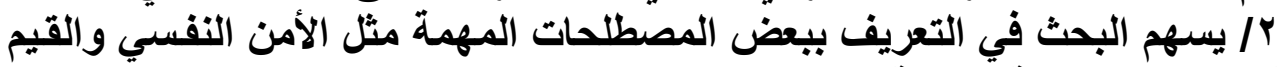

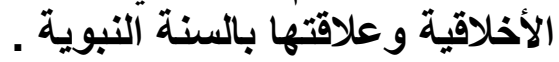

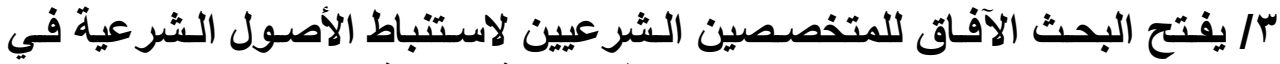
جميع مناحي الحياة من خلال البحث والاستقصاء في السنة النبوية المطهرة .

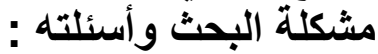


تنحصر مشكلة البحث في السؤال التالي : ما أثر القيم الأخلاقية التواردة في السنة فئة التئة النبوية في تحقيق الأمن النفسي ؟ ويتفرع من البوال هذا السؤال الرئيس عدة أسئلة فرعيّة وهي

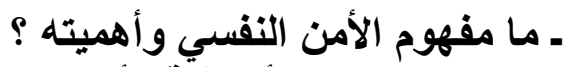

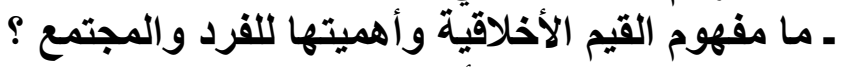

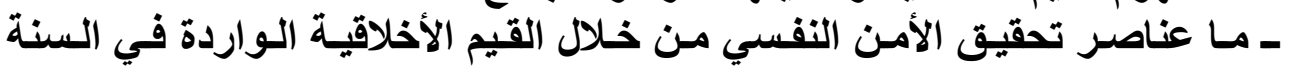

من الفروض التي يسعي هذا البحث لاختبار صدقها ما يلي :

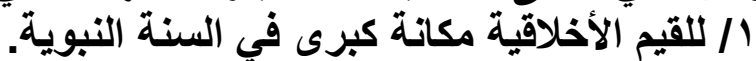

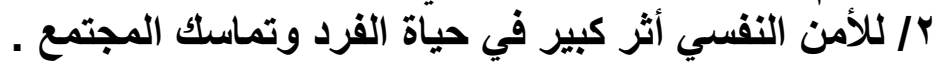

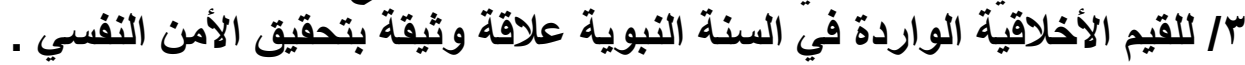

أهداف البحث : البث :

يهذف هذا البحث إلى تحقيق الأهداف الآتية :

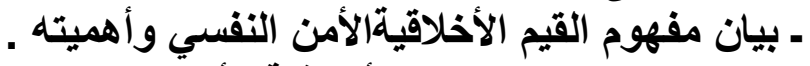

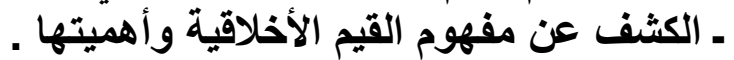

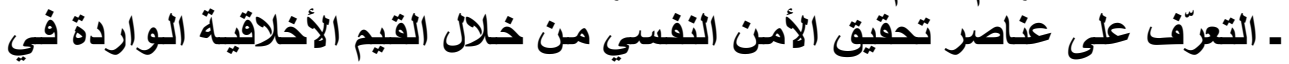

السنة النبوية .

منهج البحث :

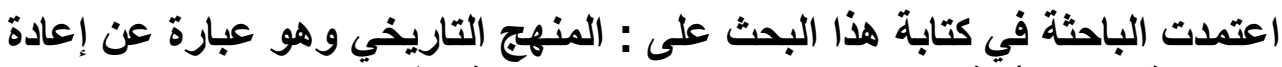

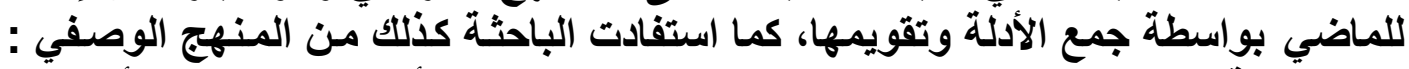

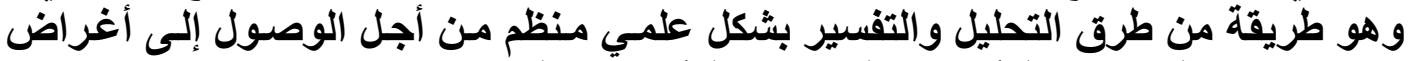

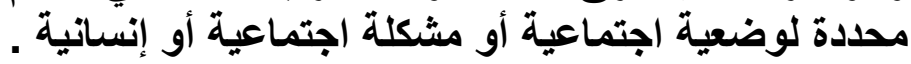

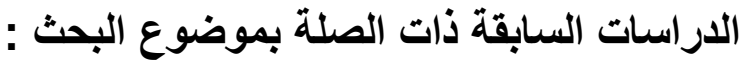

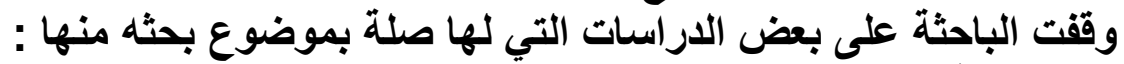

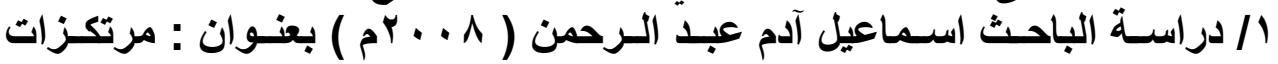

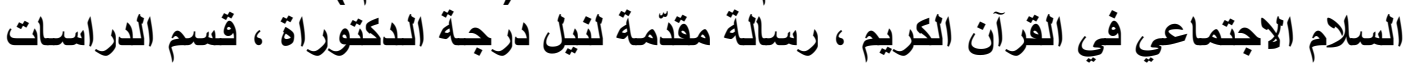

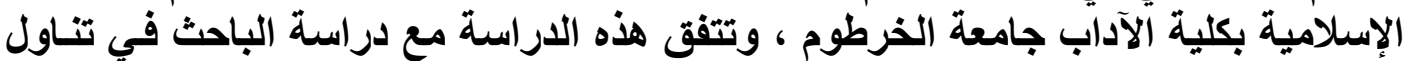

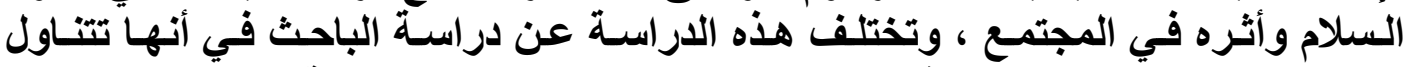

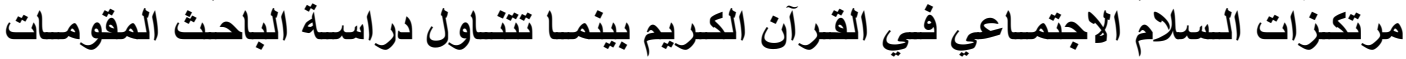

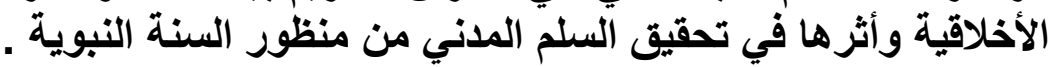

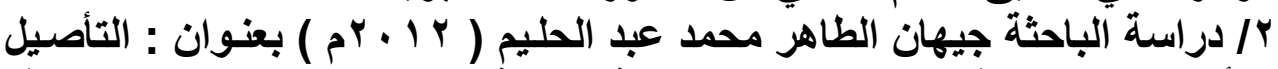

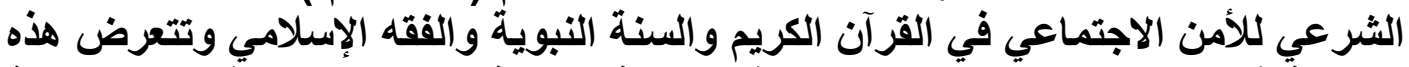

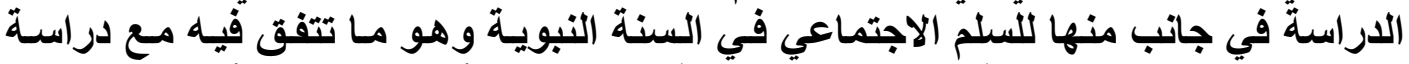

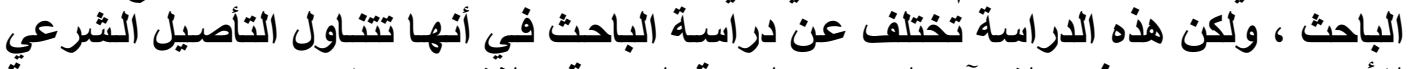

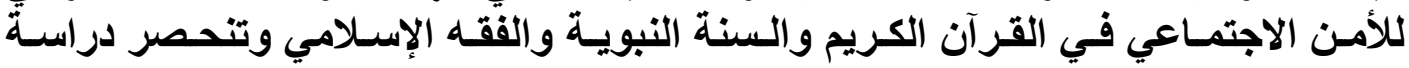


الباحث في بالتعريف بالمقومات الأخلاقية وأثرها في تحقيق السلم المدني من منظور السنة النبوية .

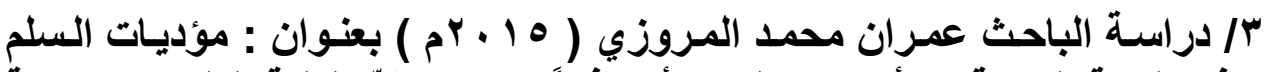

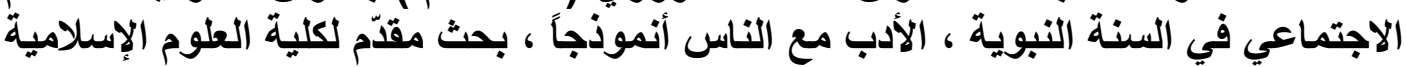

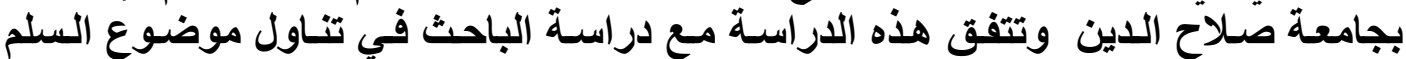

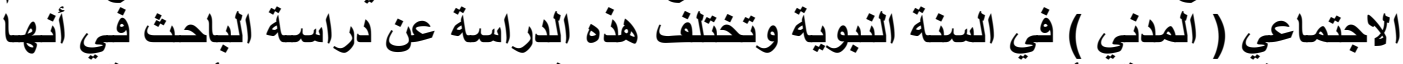

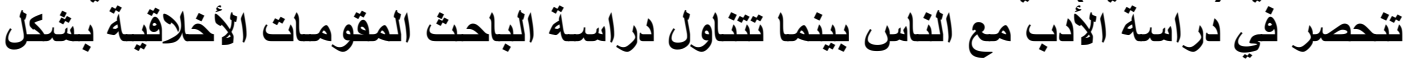

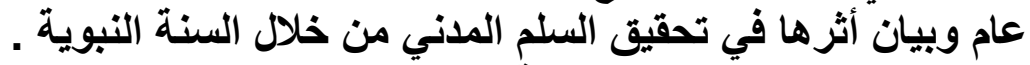

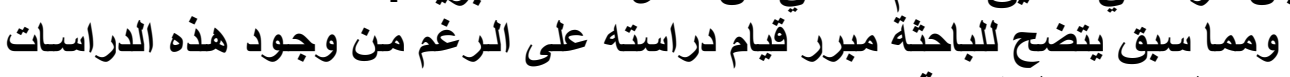
وغيرها من الاراسات المشابهة . هيكل البحث : هن الاري

يقوم هيكل البحث على مقدمة ومبحثين وخاتمة وفهرس للمصادر والمراجع على

$$
\begin{aligned}
& \text { النحو التالي : } \\
& \text { مقدمة : }
\end{aligned}
$$

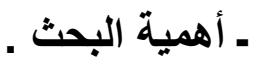

$$
\begin{aligned}
& \text { ـ مشكلة البحث . مثبث. }
\end{aligned}
$$

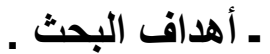

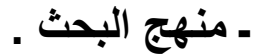

$$
\begin{aligned}
& \text { ـ هيكل البحث . ماليث. } \\
& \text { المبحث الأول : مفهوم الأمن النفسي وأهميته } \\
& \text { وفيه مطلبان : }
\end{aligned}
$$

ـ المطلب الأول : مفهوم الأمن النفسي في اللغة والاصطلاح .

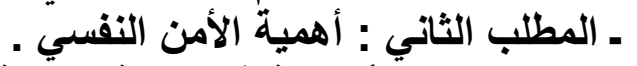

المبحث الثاني : القيم الأخلاقية في السنة النية الامنية النفية وأثرها في تحقيق الأمن النفسي وفيه مطلبان :

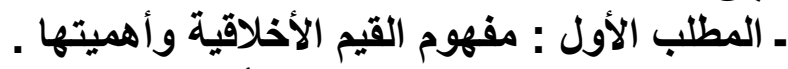

ـ المطلب الثاني : مظاهر تحقيق الأمن النفسي من خلافل الثمئه القيم الأخلاقية الواردة في

السنة النبوية .

الخاتمة :

نتائج البحث وتوصياته .

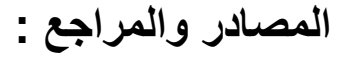

بترتيب حروف المعجم بتقايم اسم الكتاب على اسم المؤلف . 


\section{المبحث الأول \\ هفهوم الأمن النفسي وأهميته}

\section{المطلب الأورل}

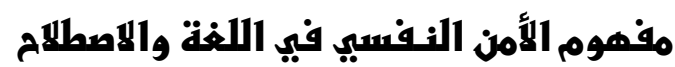

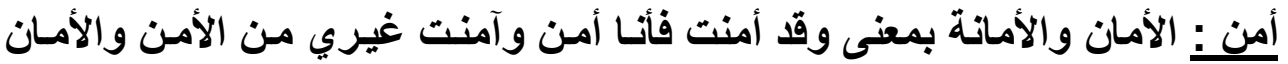

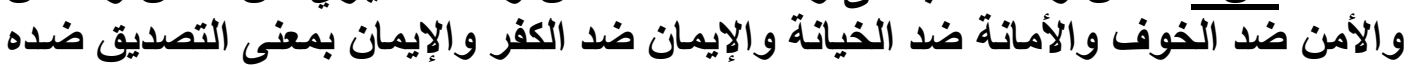

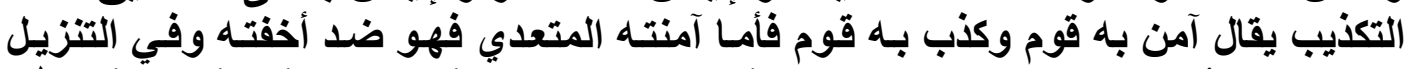

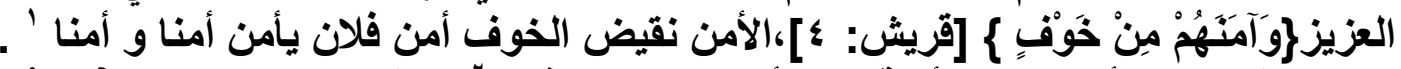

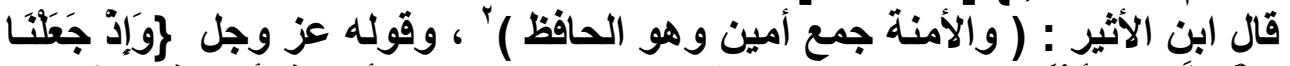

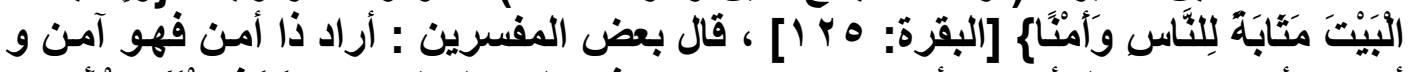

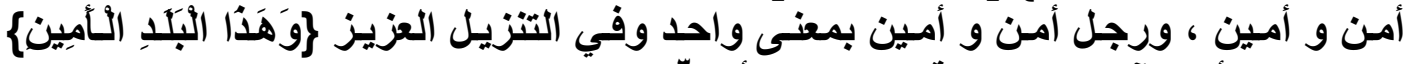

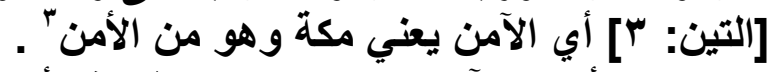

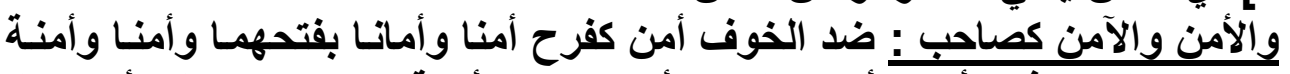

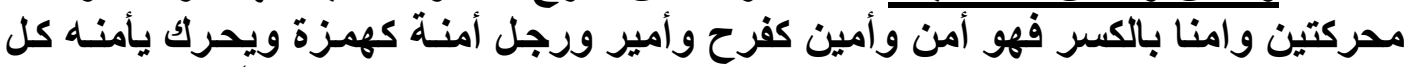

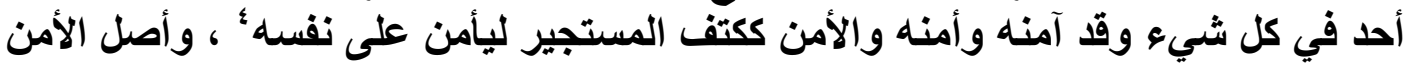

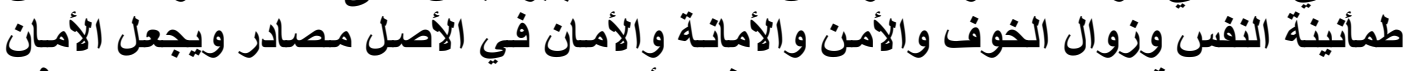

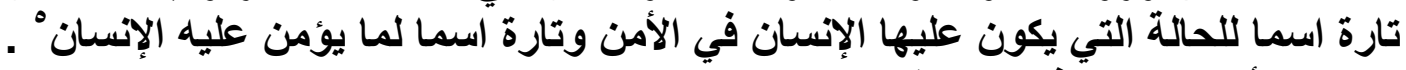

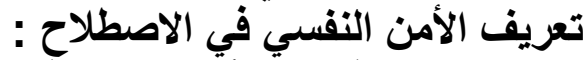

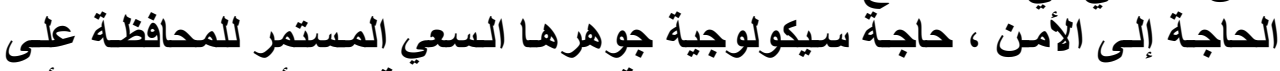

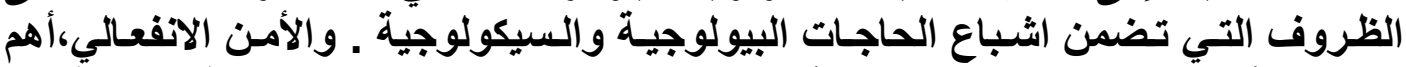

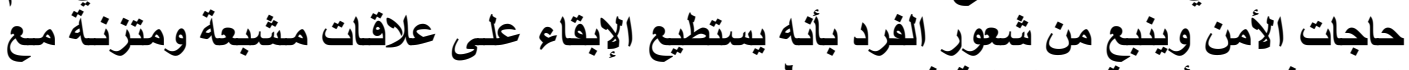

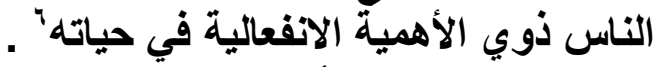

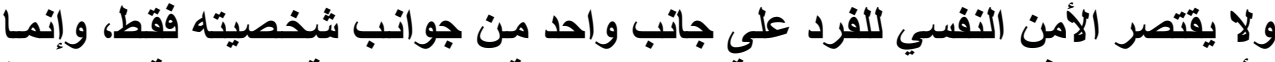

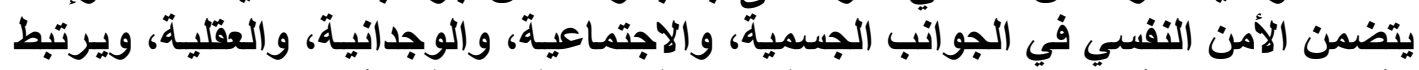

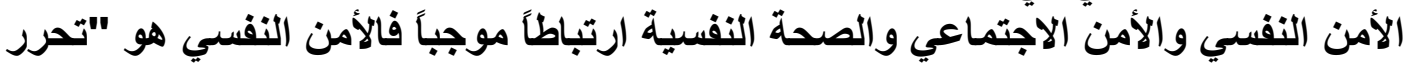

' ' لسان العرب : محمد بن مكرم بن منظور المصري ، دار صـادر بيروت ، الطبعة الأولى ، 99 ام 'ـ النهاية في غريب العديث والأثر : المبارك بن محمد بن الأثثر الجزري ، دار المكتبة العلمية بيروت

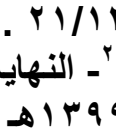

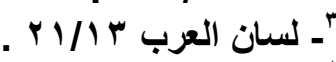

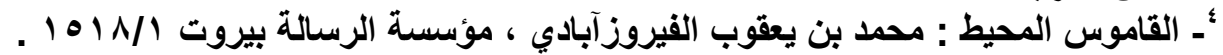

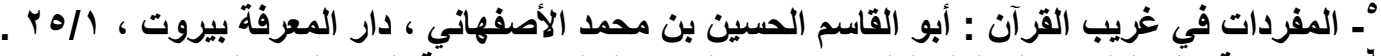

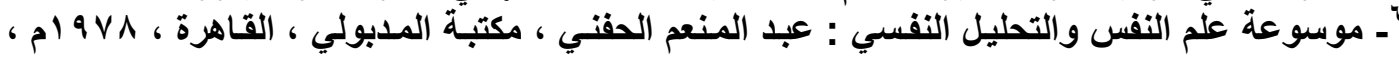


القرد من الخوف والوصول إلى حالة الاطمئنـان على صحته ومستقبله، والشعور بالثقة

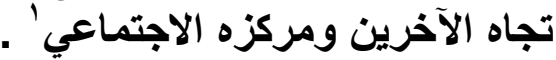

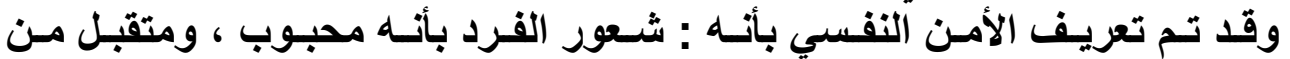

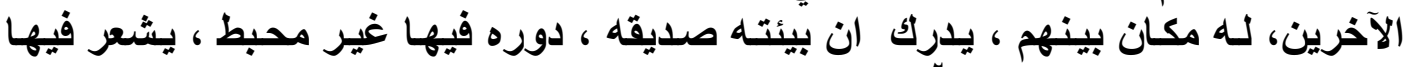

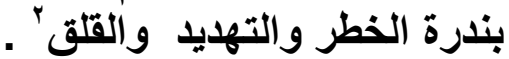

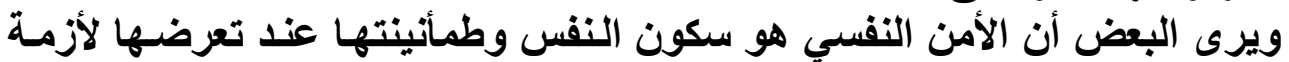

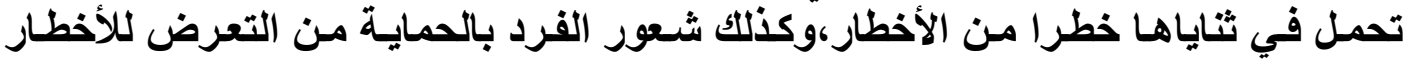

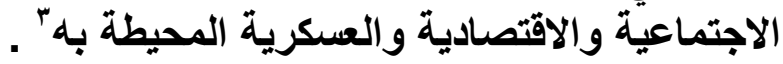

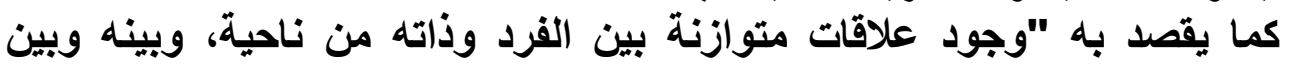

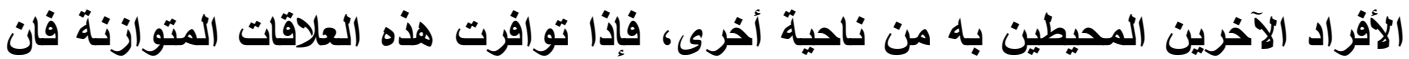

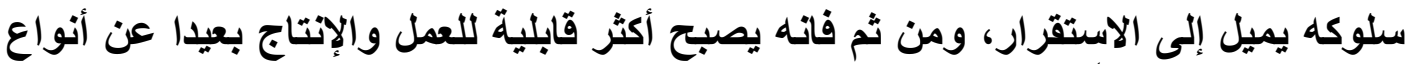

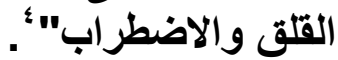
ويعرف الأمن النفسى كذلك بأنه : الطمأنينة النفسية أو الانفعالية لادى الفرد، وحالة

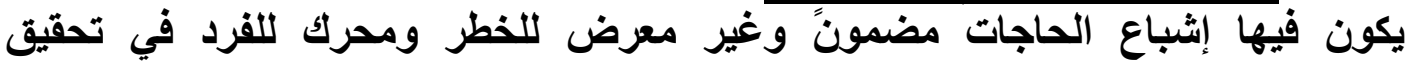

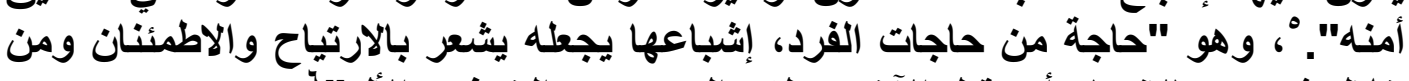

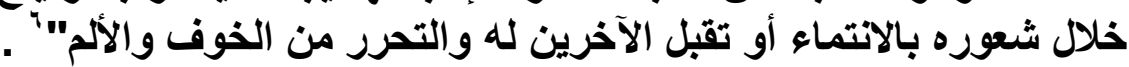

ـ ـ الأسس النفسية لآراء الماوردي التربويـة : جمـال حسين الألوسي ، مطبعة بغداد ، بغداد، 919 ام،

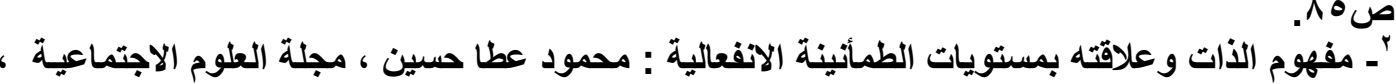

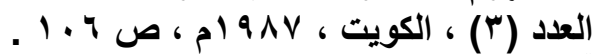

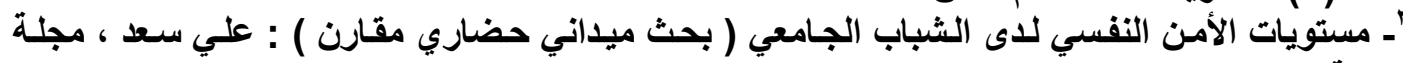

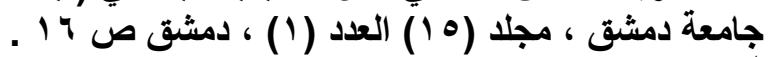

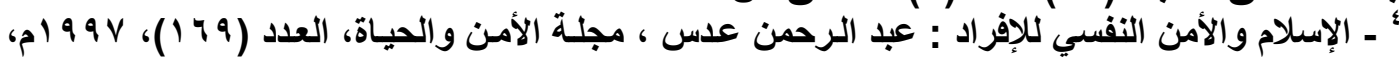

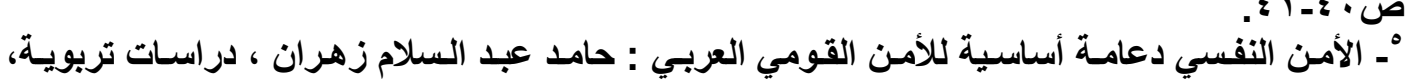

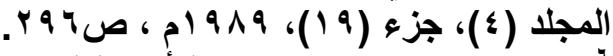

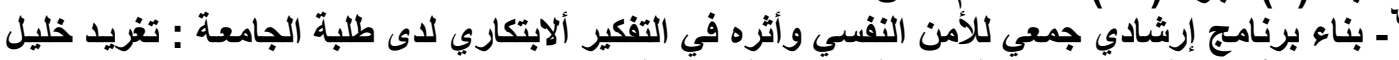

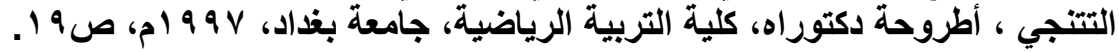




\section{المطلب النغانسي}

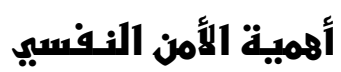

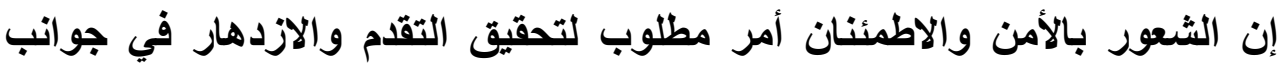

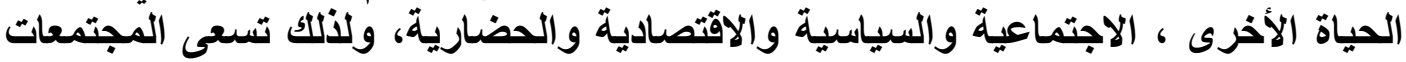

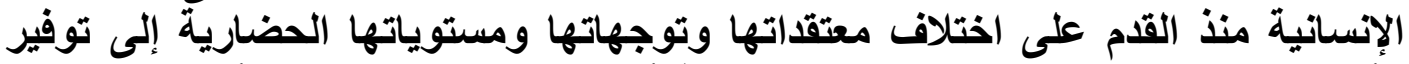

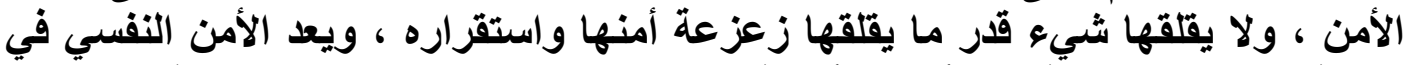

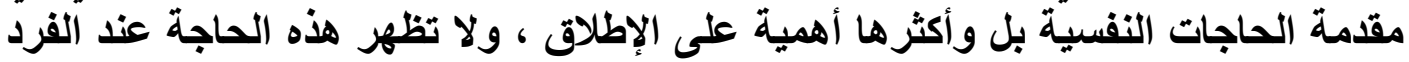

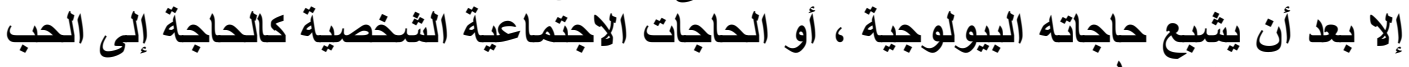

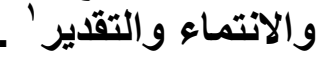

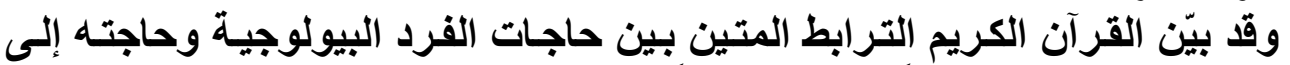

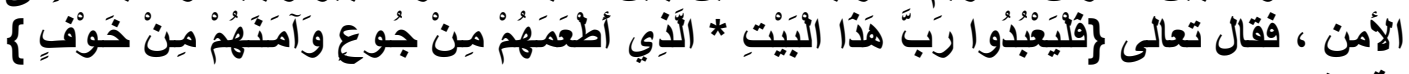

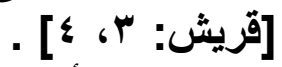

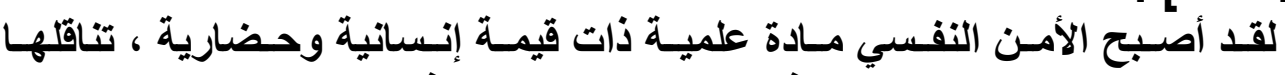

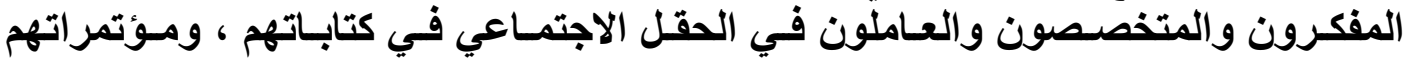

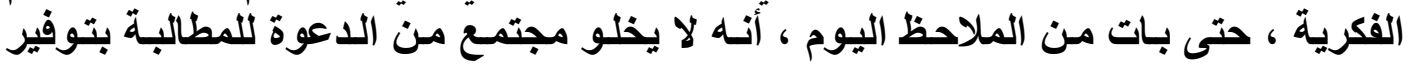

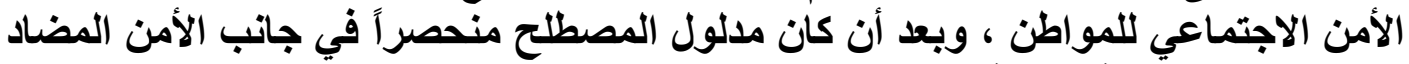

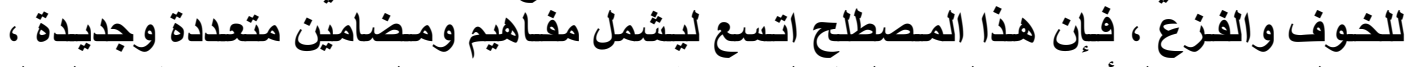

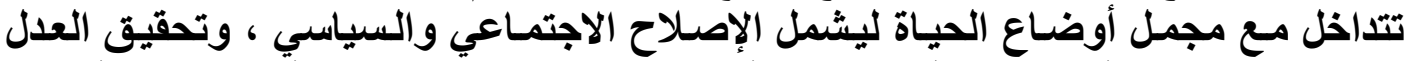

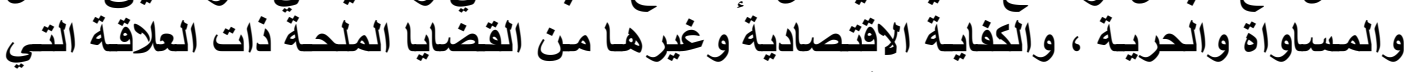

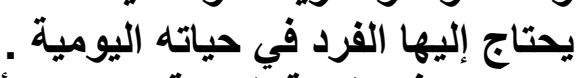

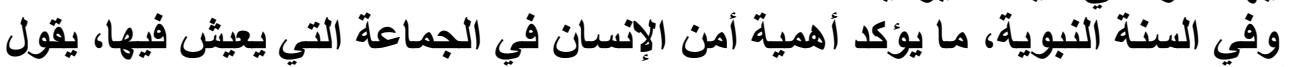

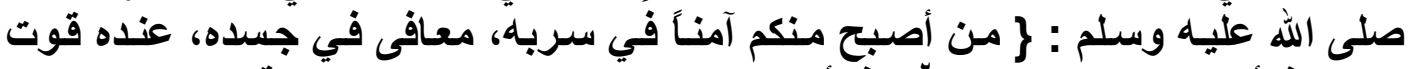

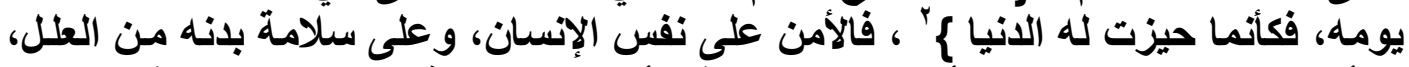

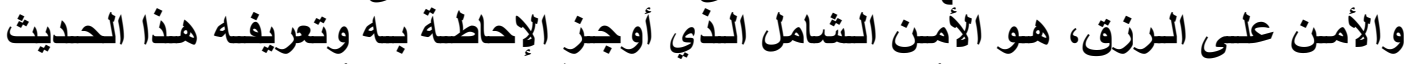

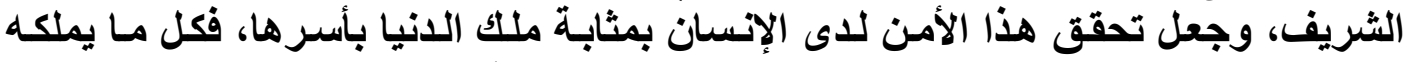

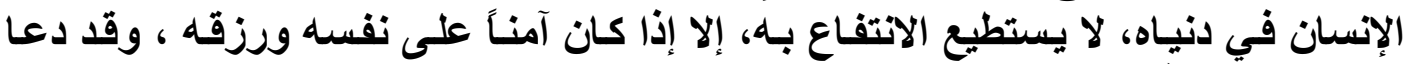

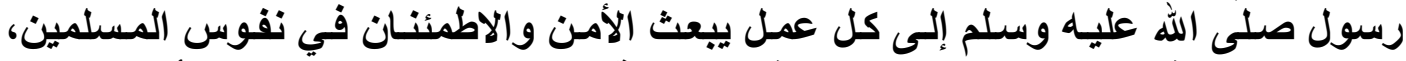

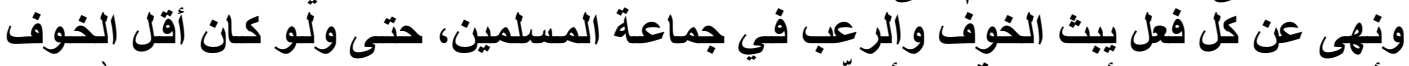

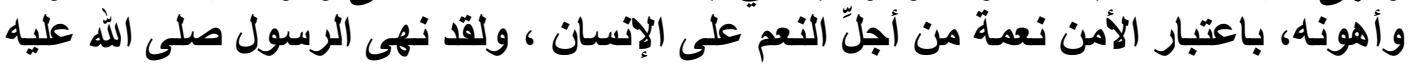

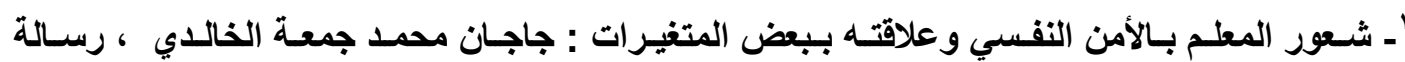

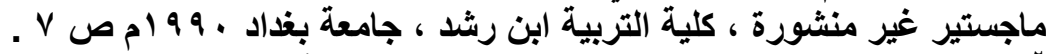

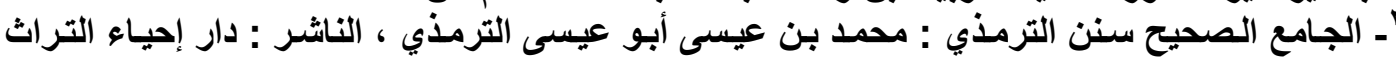

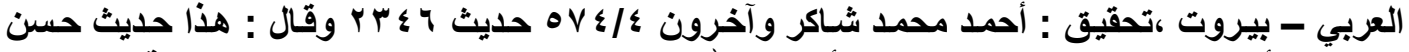

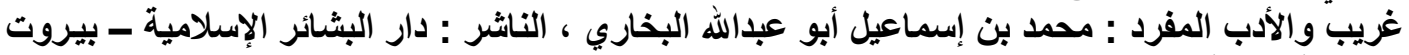

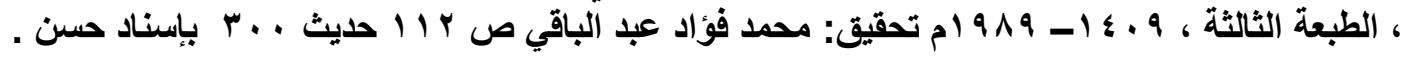




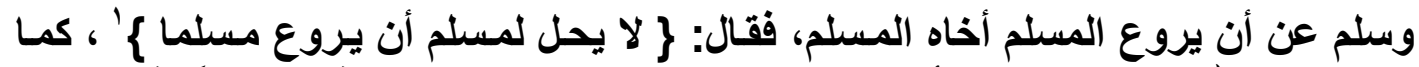

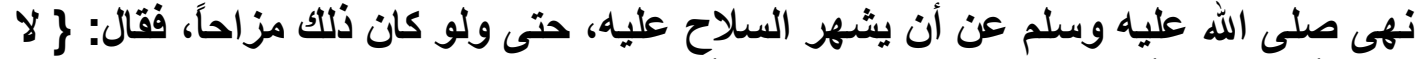

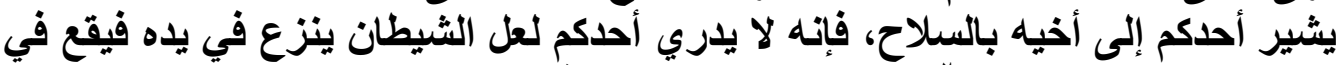

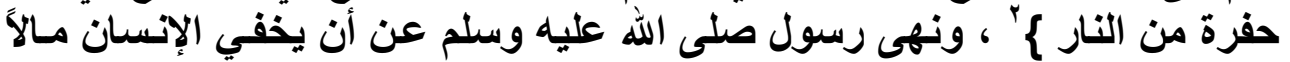

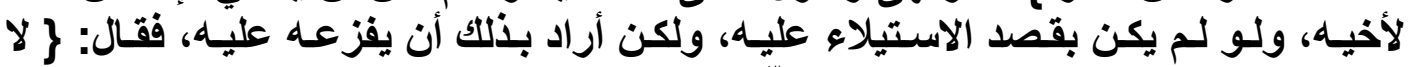

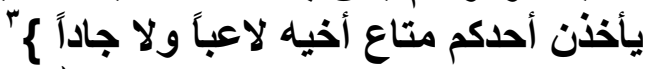

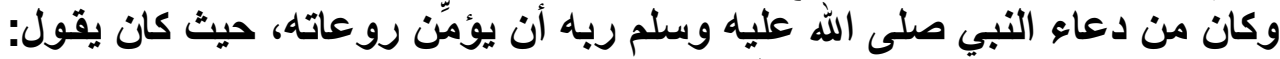

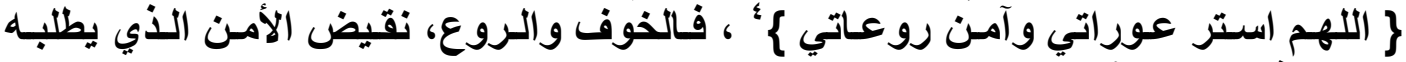
المسلم في دنياه وآخرته.

'ـ سنن أبي داود : سليمان بن الأشـعث أبو داود السجستاني الأزدي ، تحقيق : محمد محيبي الدين عبد

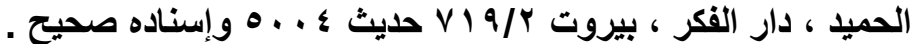

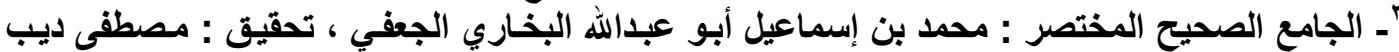

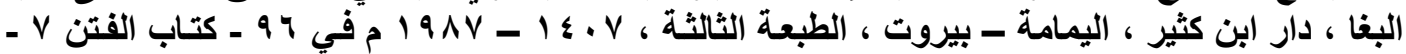

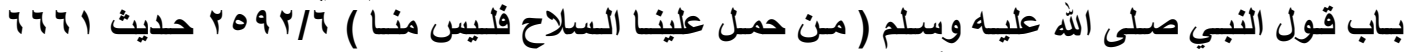

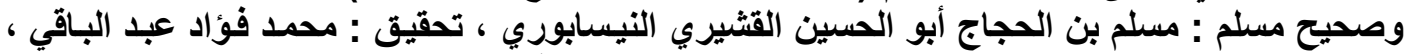

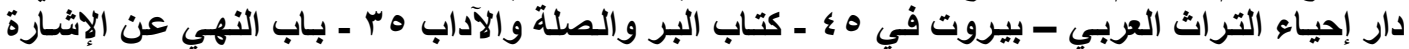

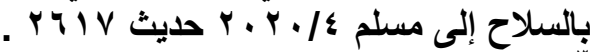

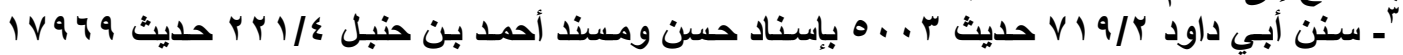

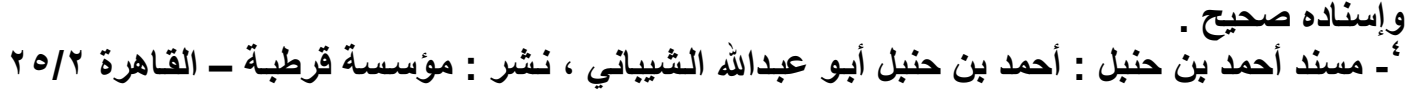




\title{
المبمث الثاني \\ القيم الأخلاقية في السنة النبوية وأثرها في تصقيق الأهن النفسي
}

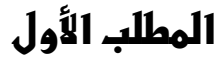 \\ مفهوم القيم الأفلاقية وأهميتهما
}

$$
\text { مفهوم مصطلح ( القيم ) : }
$$

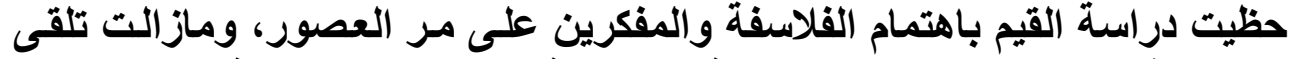

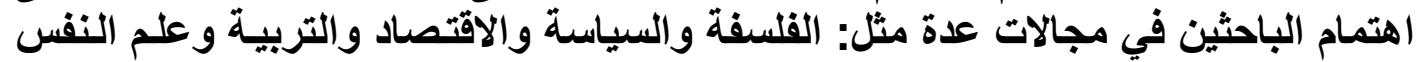

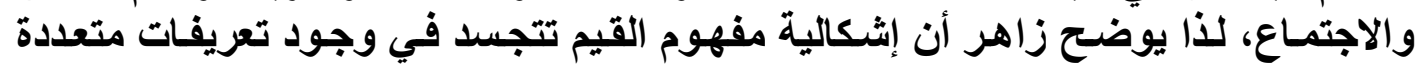

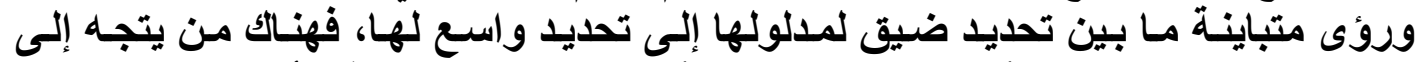

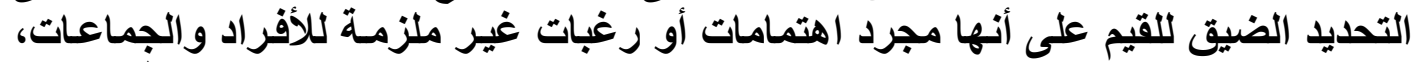

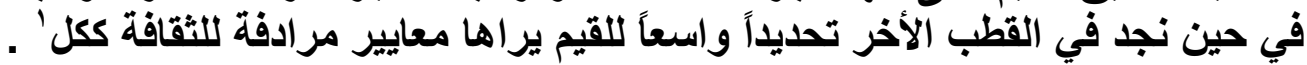

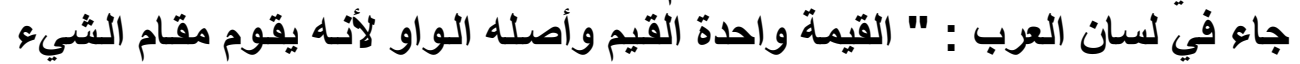

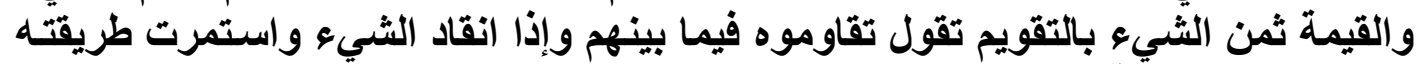

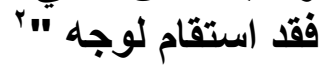

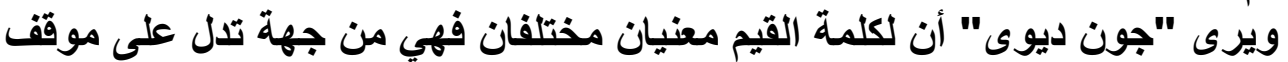

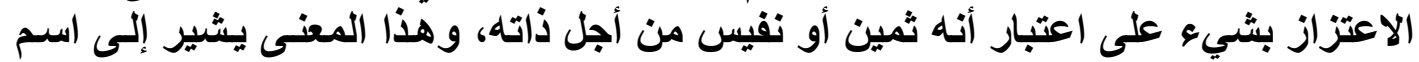

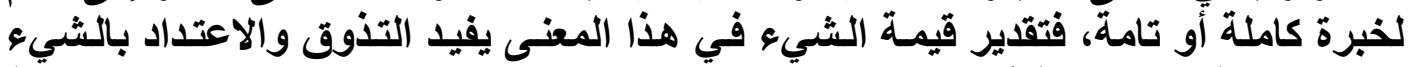

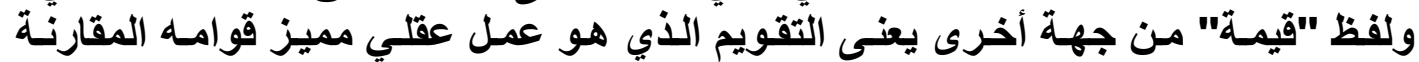

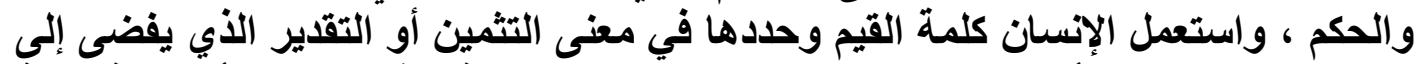

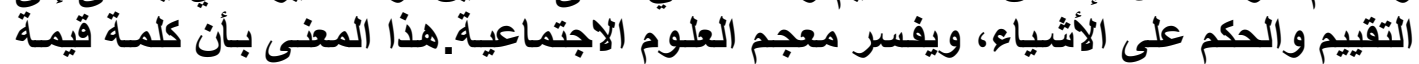

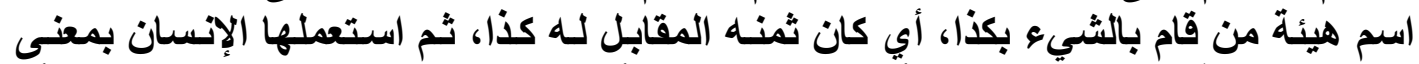

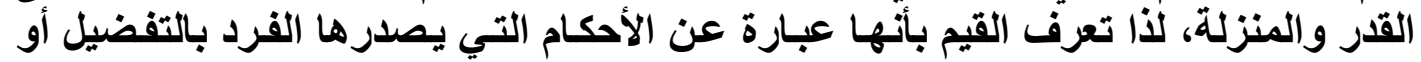

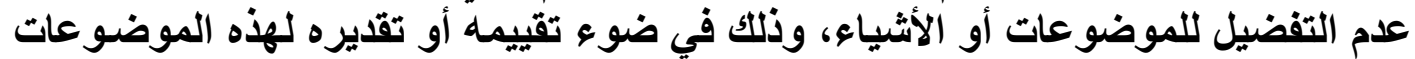

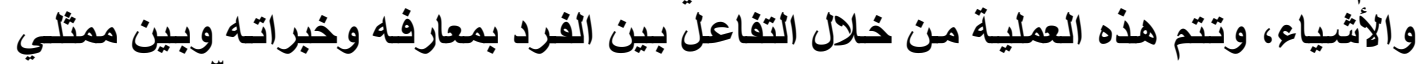

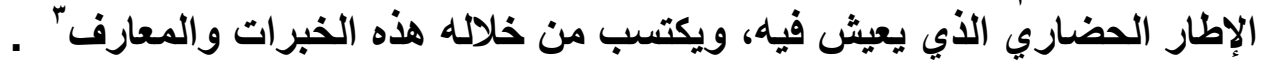

ـ ـ القيم في العمليـة التربويـة، سلسة معسالم تربويـة : ضياء زاهر ، القـاهرة: مؤسسسة الخليج العربي

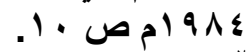

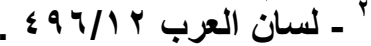

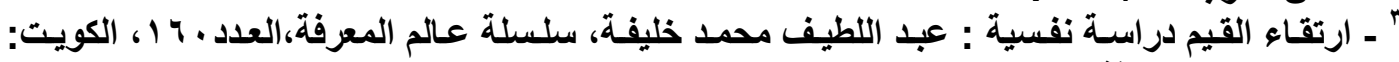

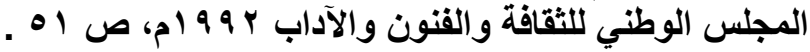




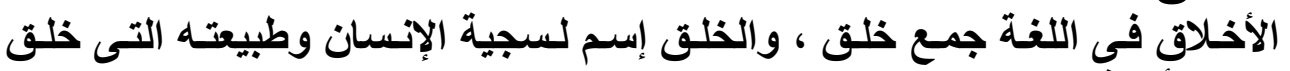

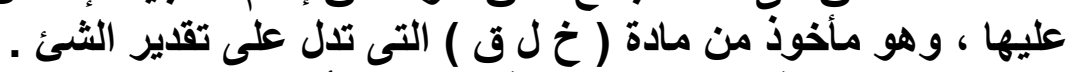

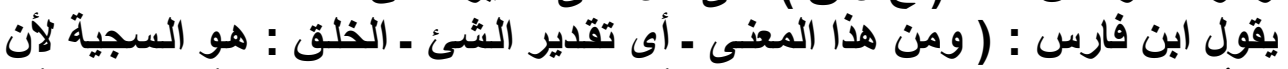

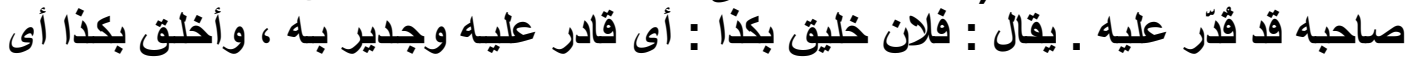

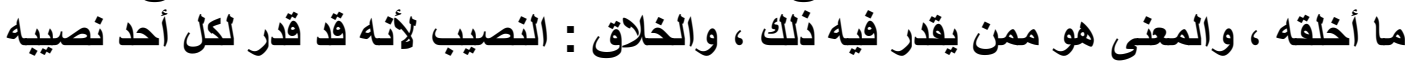

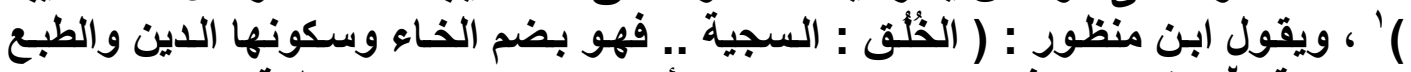

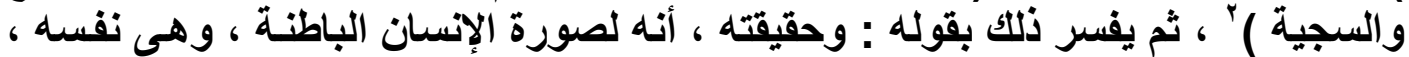

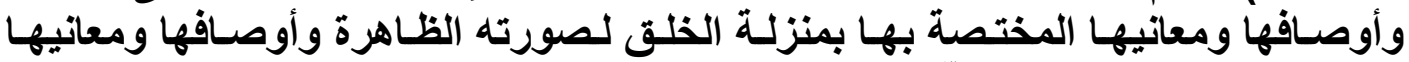

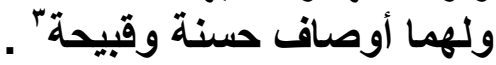

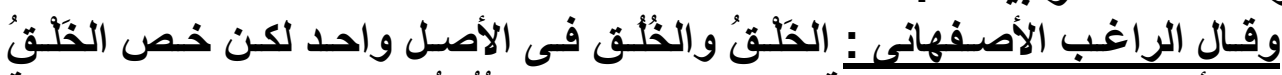

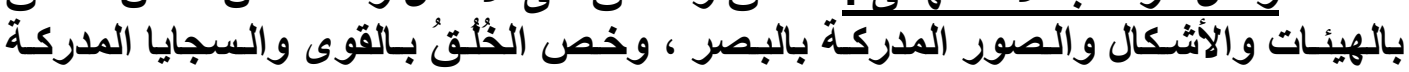

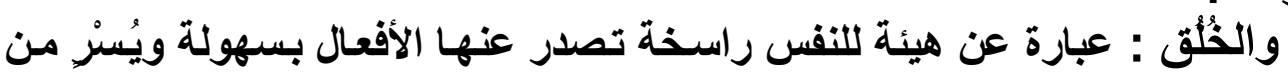

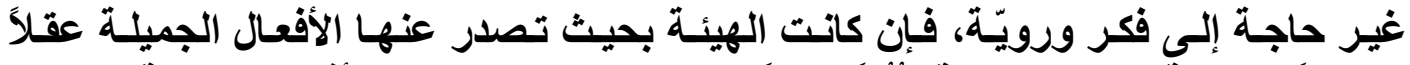

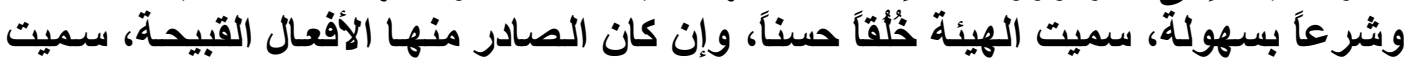

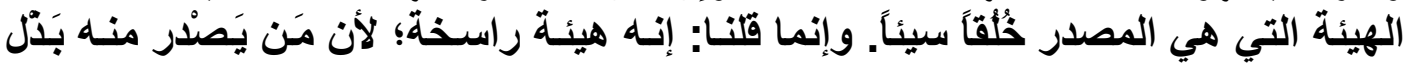

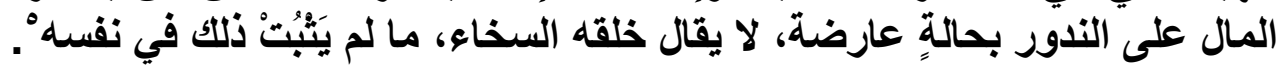

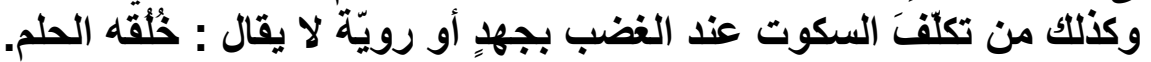

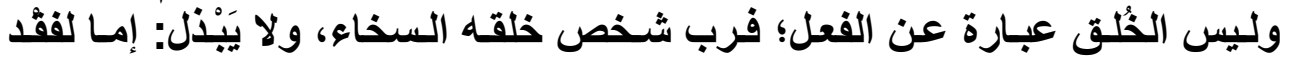

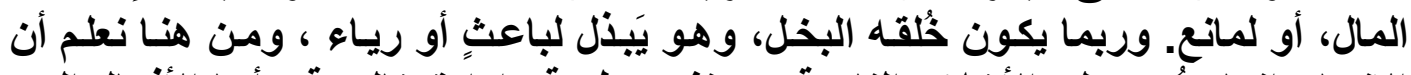

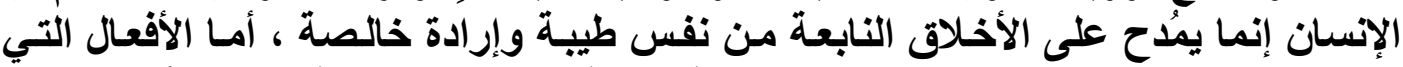

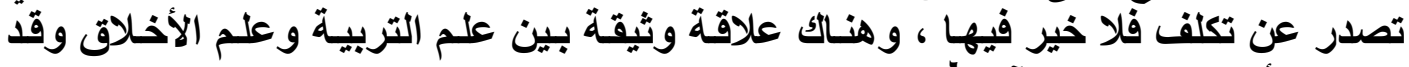

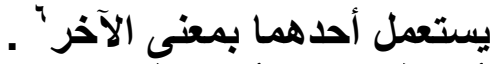

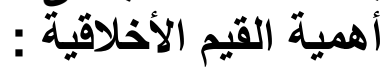
للأخلاق أهمية بالغة، وأثراً كبيراً في حياة الأفراد والجماعات والأمم؛ فالأخلاق

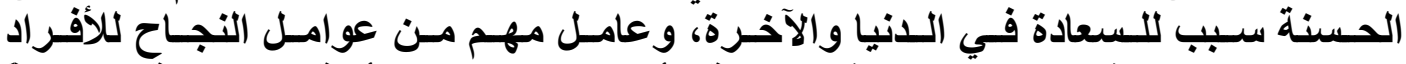

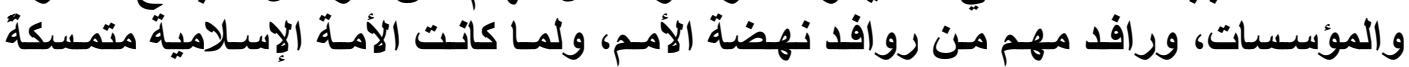

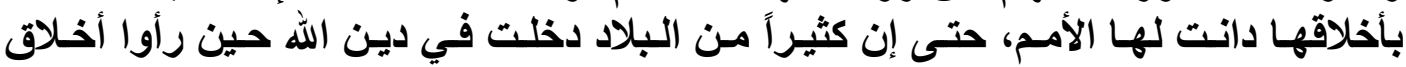

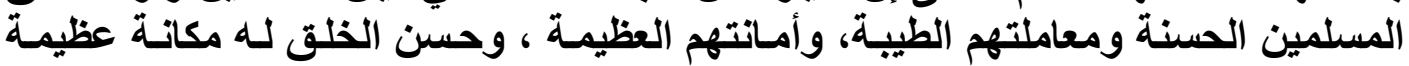

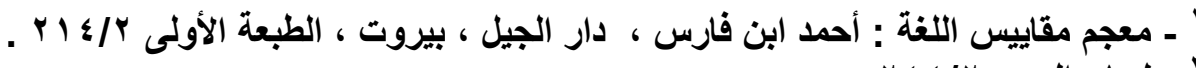

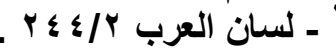

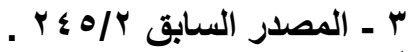

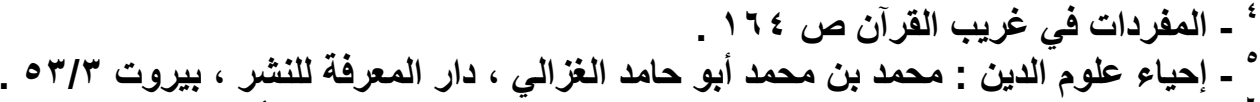

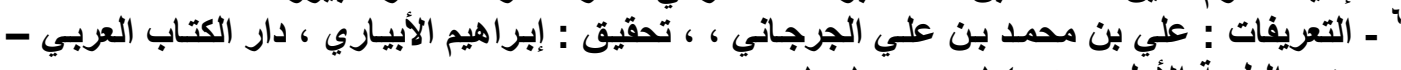

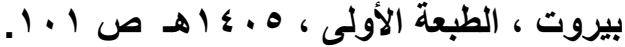




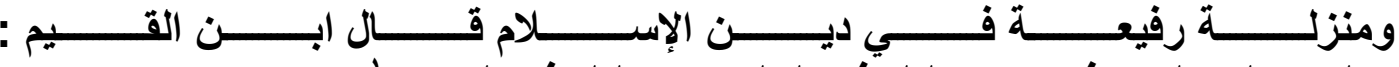

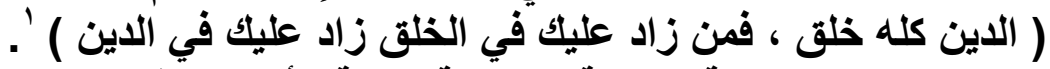

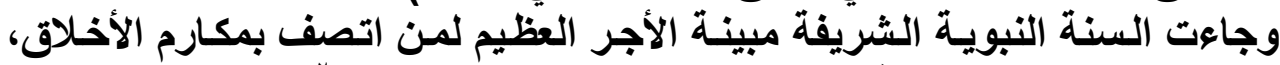

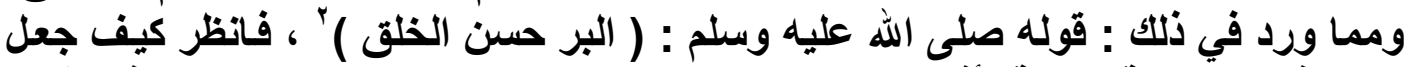

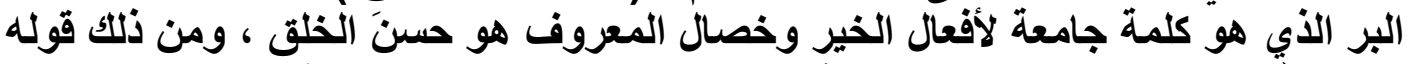

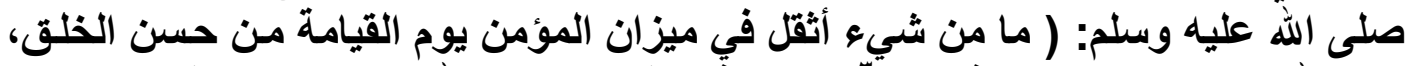

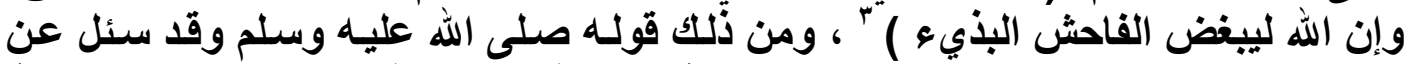

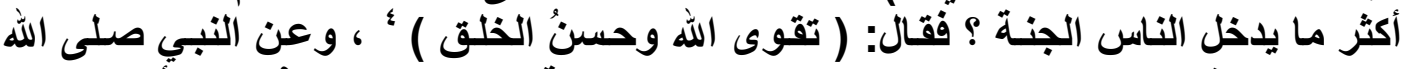

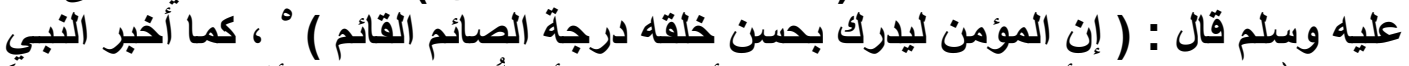

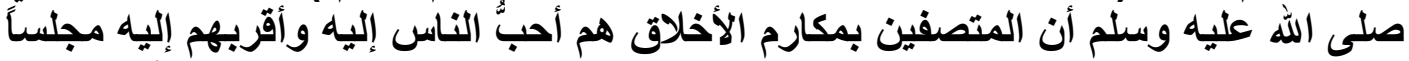

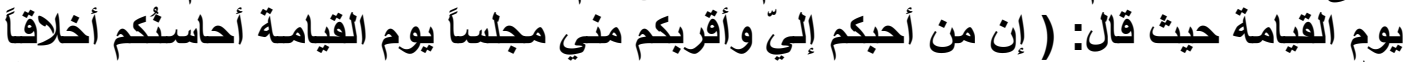

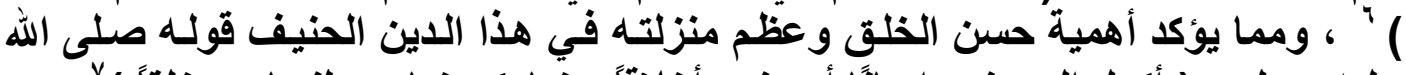

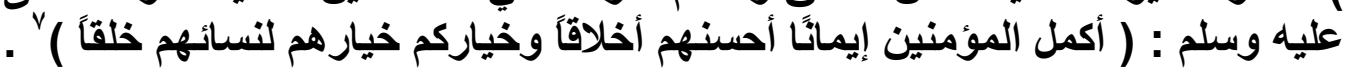

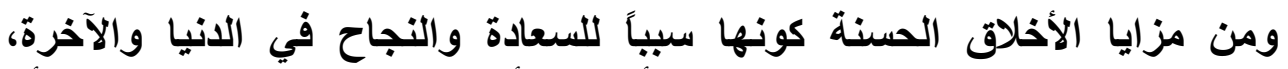

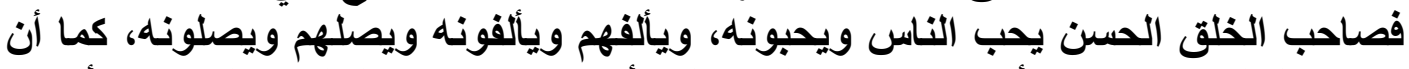

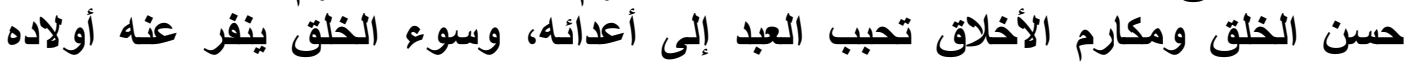

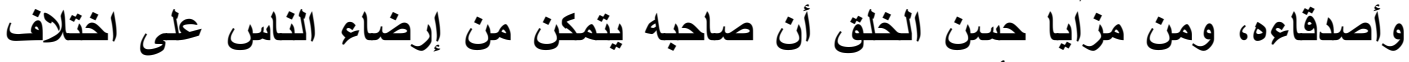

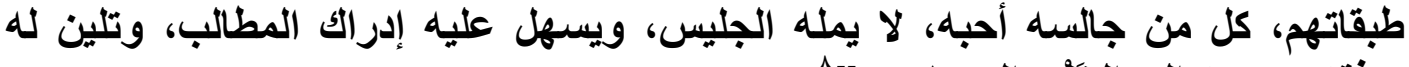

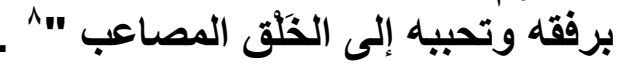

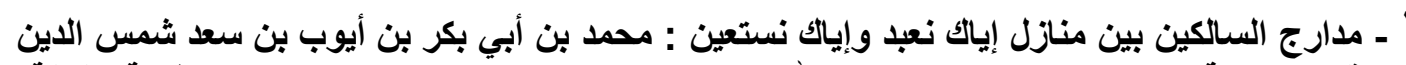

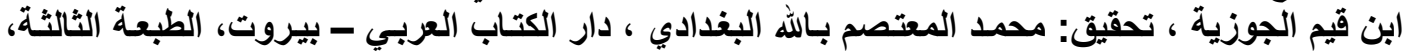
ا

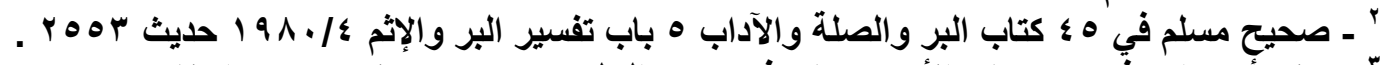

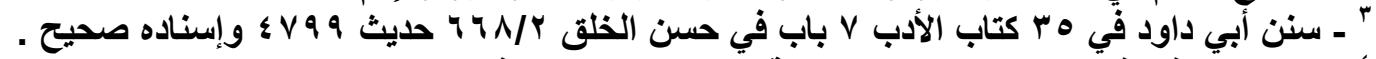

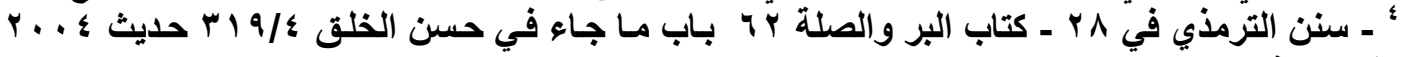

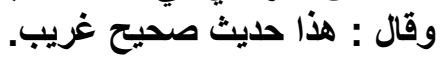

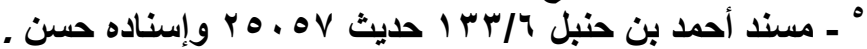

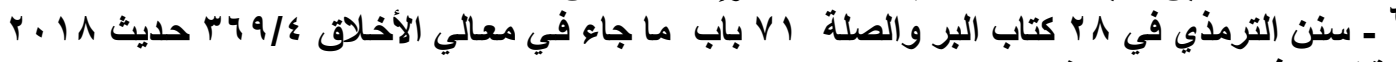

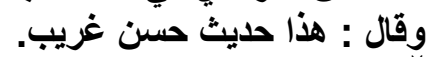

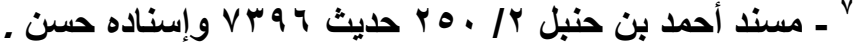

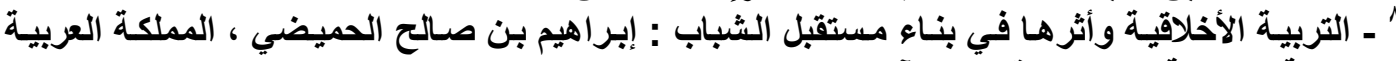

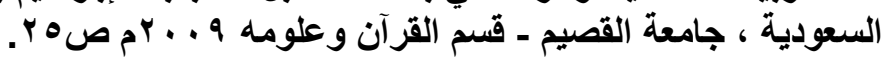




\section{1المطلب الثناني}

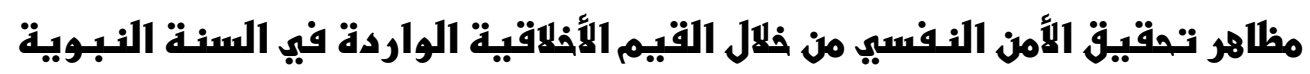

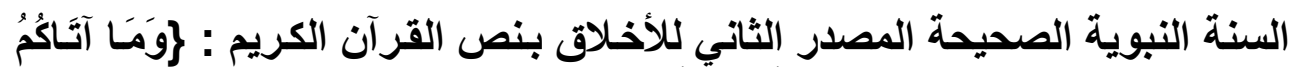

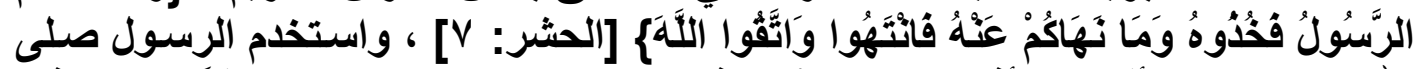

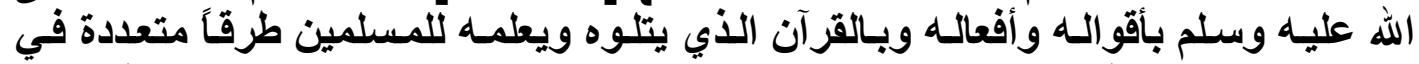

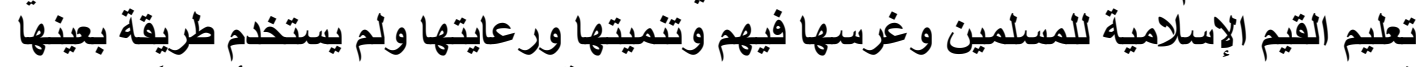

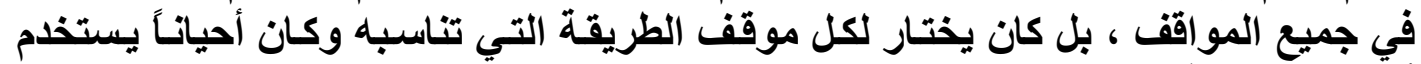

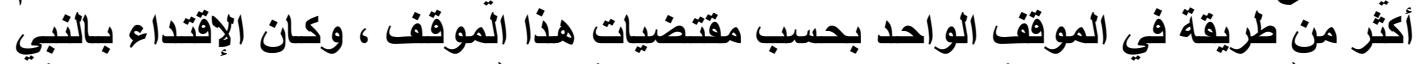

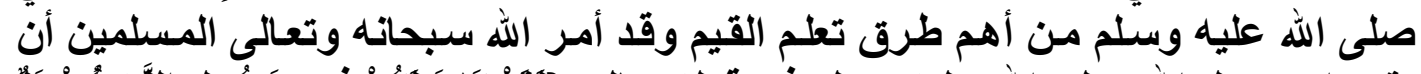

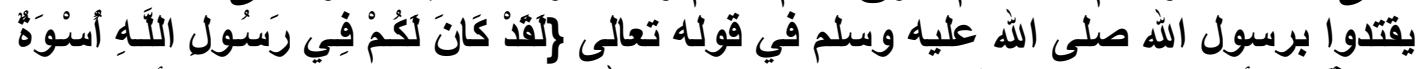

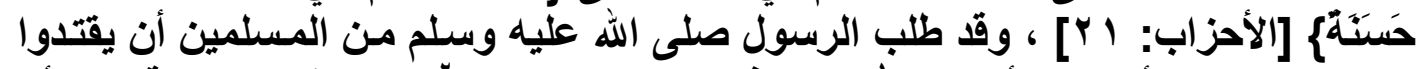

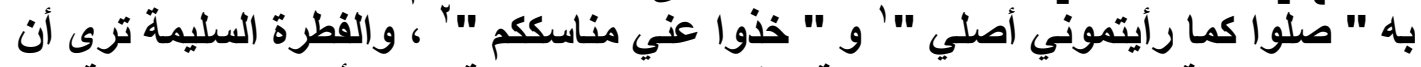

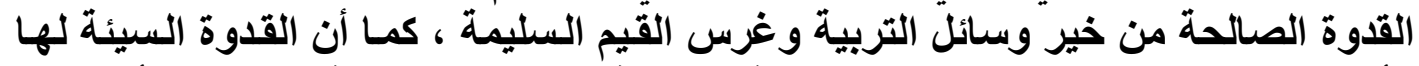

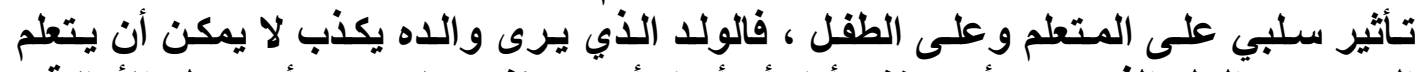

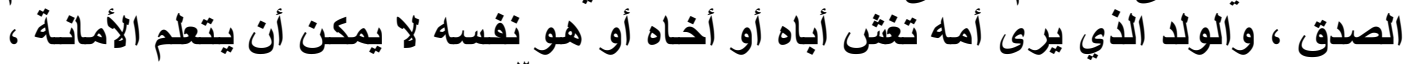

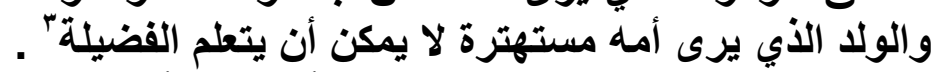

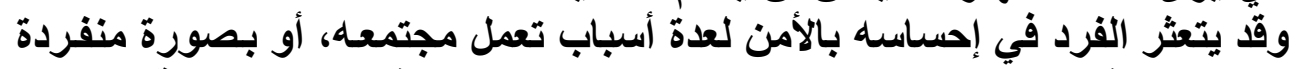

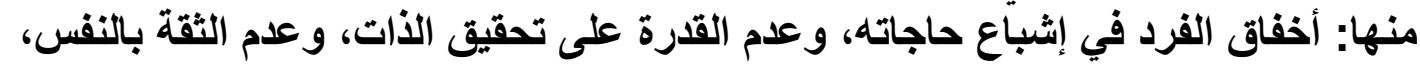

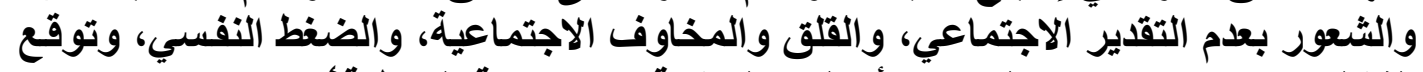

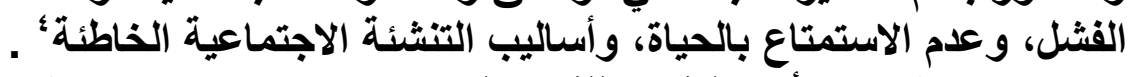

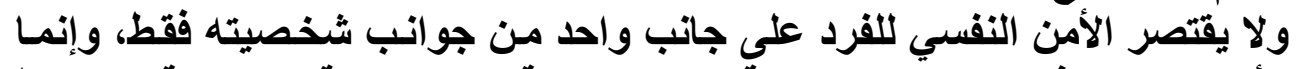

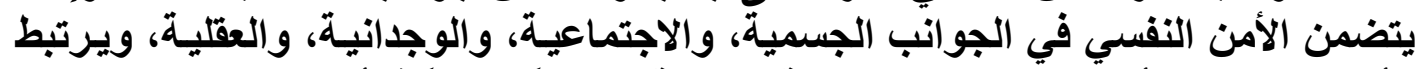

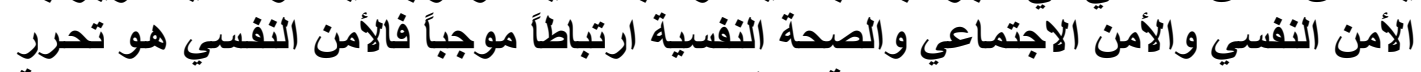

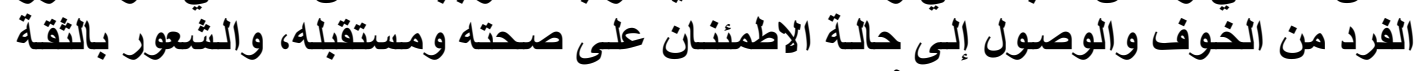

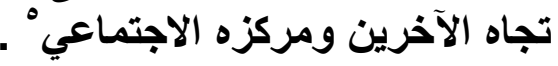

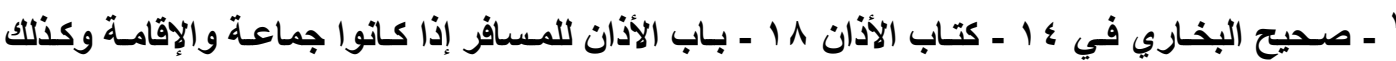

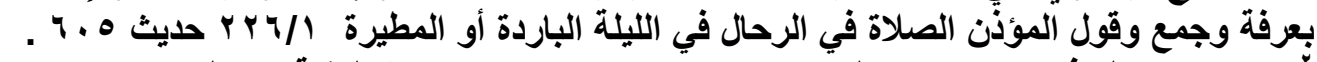

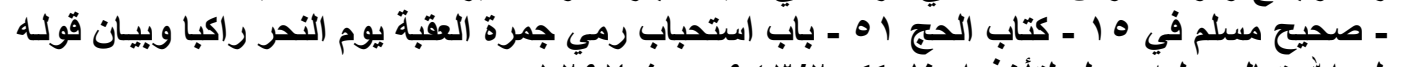

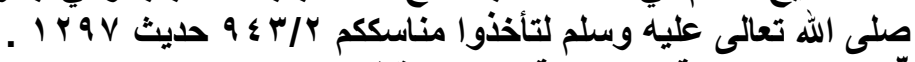

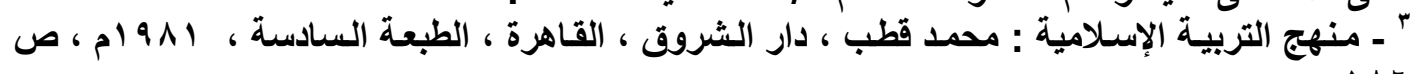
" ـ سلؤك الوالدين الإيذائي للطفل وأثره على الأمن النفسي له : جمال حمزة ، مجلة علم النفس، ع ه ه،

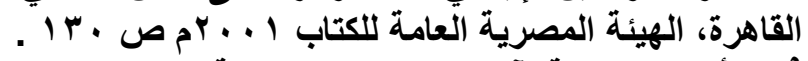

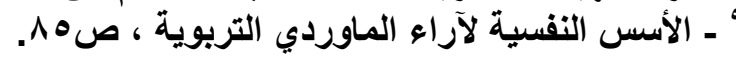


وهنالك ستة قيم وعناصر أساسية تشكل مفهوم الأمن النفسي وهي' :

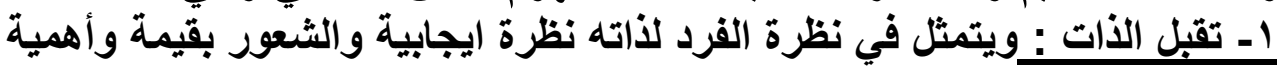

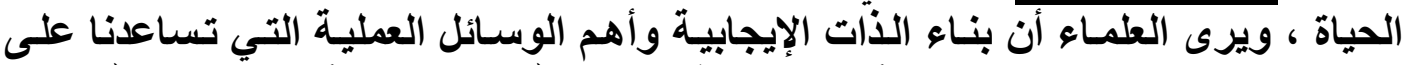

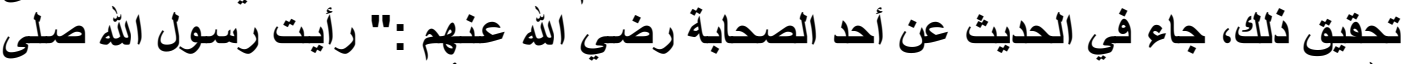

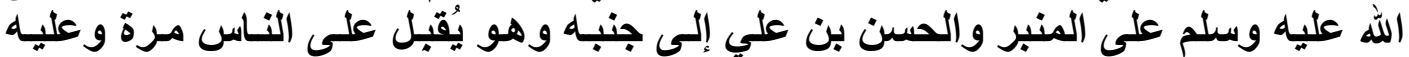

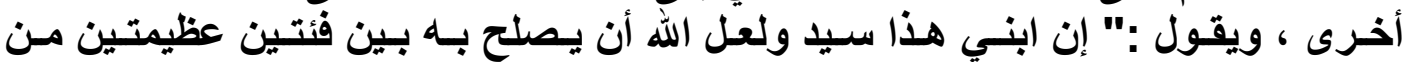

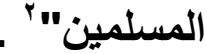

بـالعلاقة الايجابية مع الآخرين : وتثمثل في قدرة الفرد على إقامة علاقات ايجابية

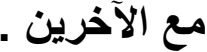

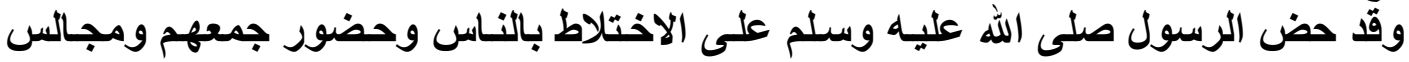

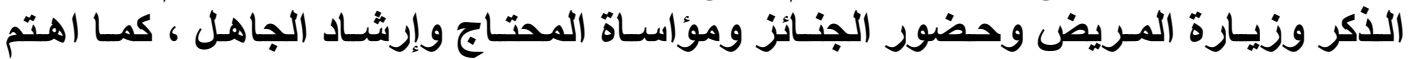

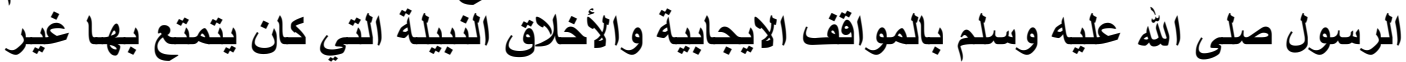

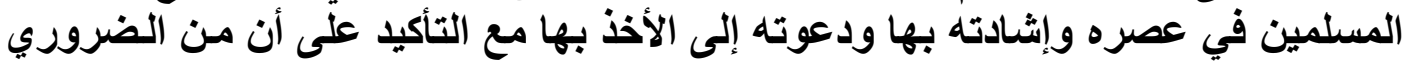

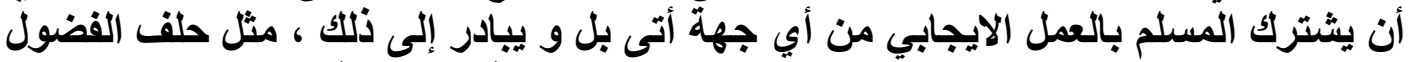

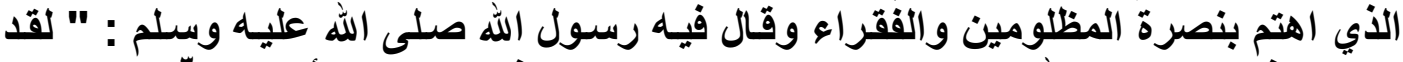

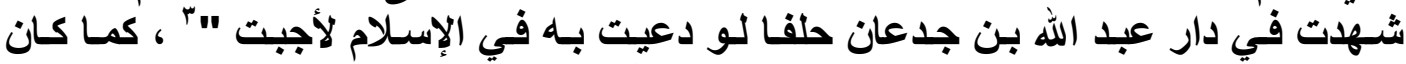

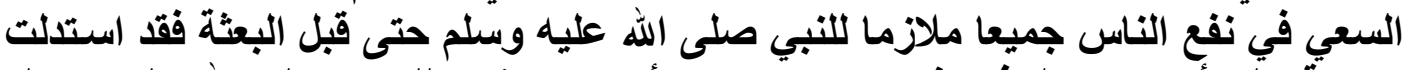

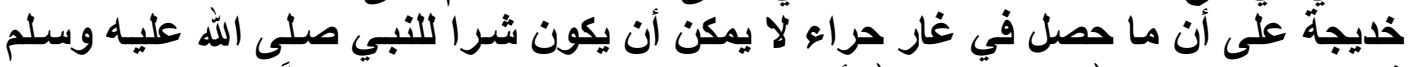

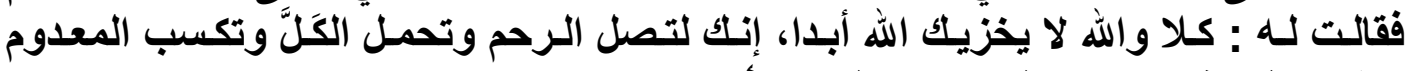

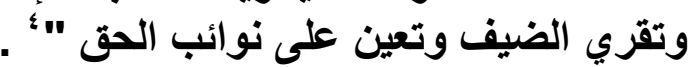

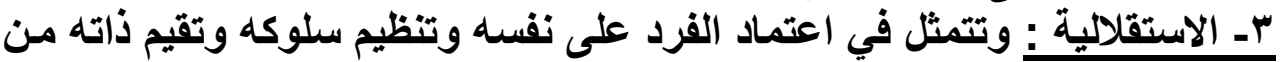

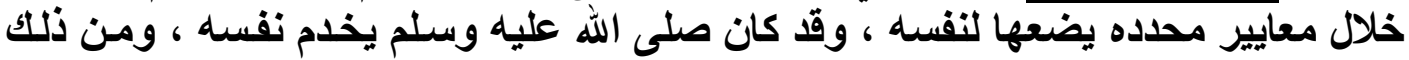

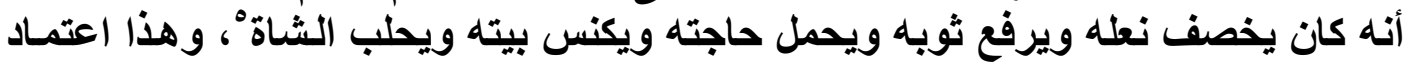

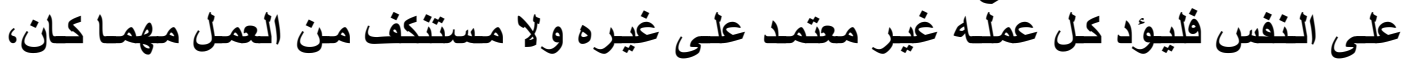

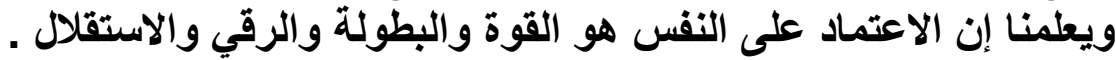

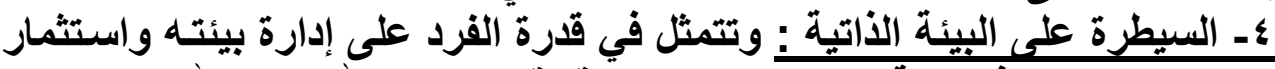

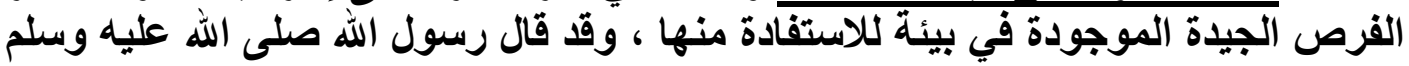

' ـ الأمن النفسي والثعور بالوحدة النفسية لاى عينة من المرضى المرفوضين أسرياً والمقبولين أسرياً

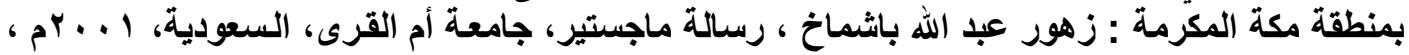

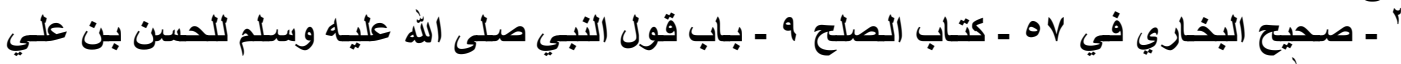

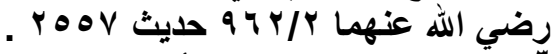

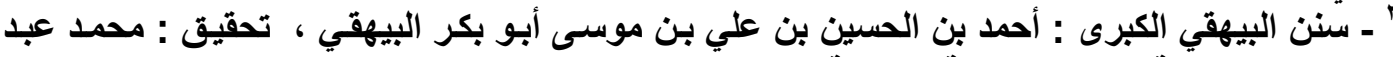

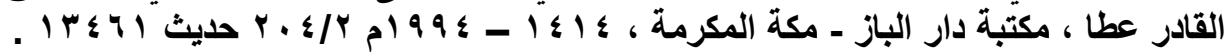

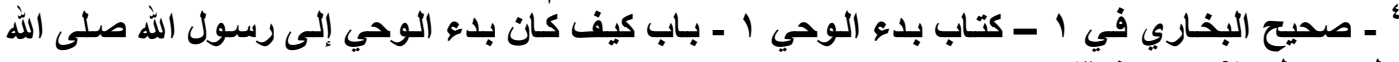

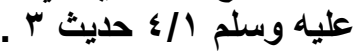

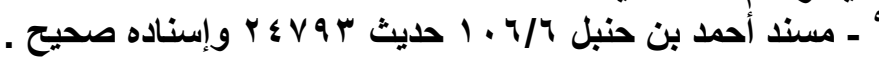




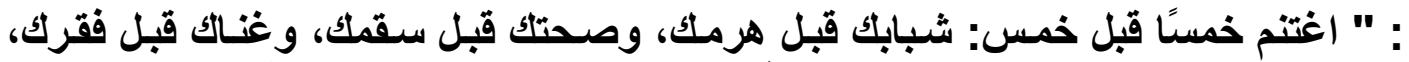

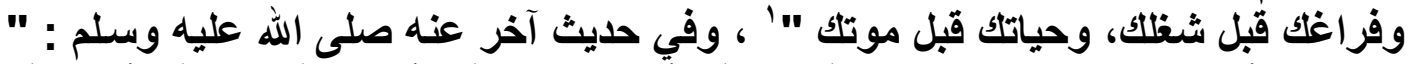

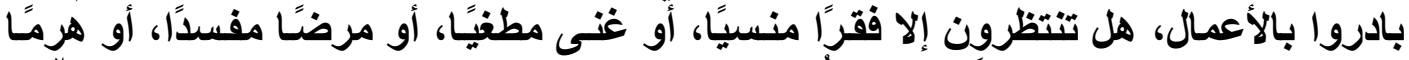

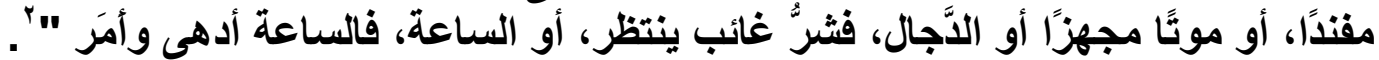

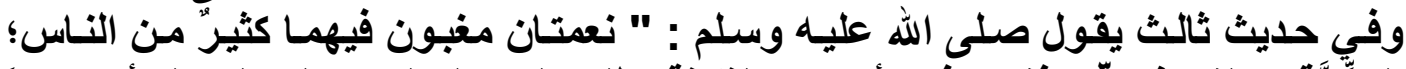

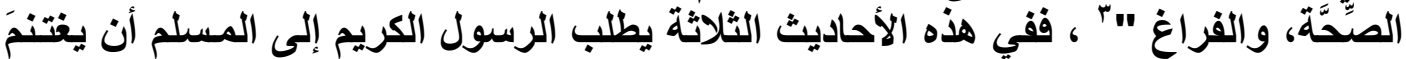

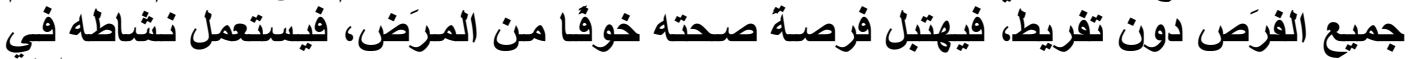

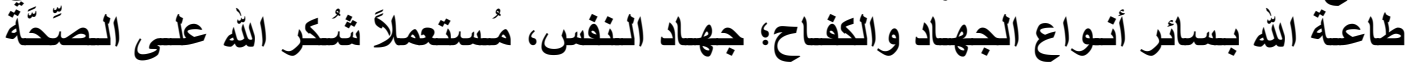

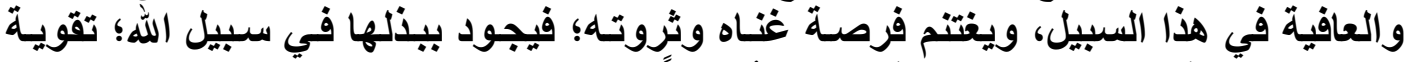

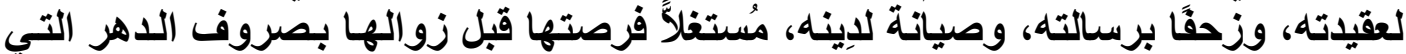

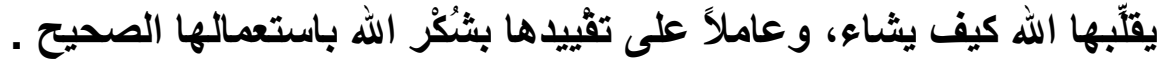

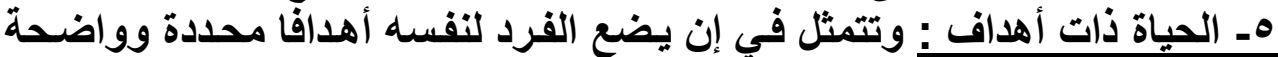

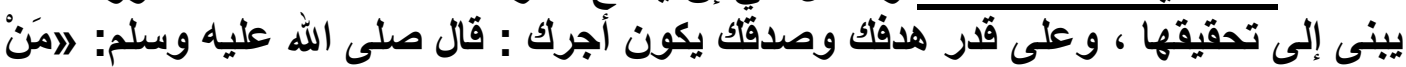

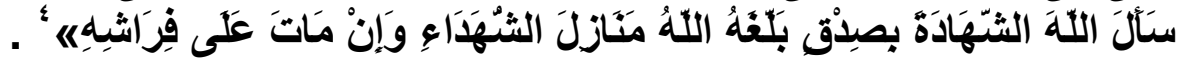

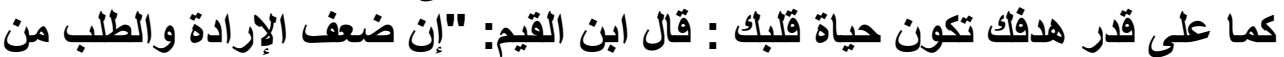

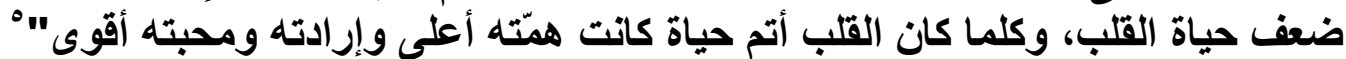

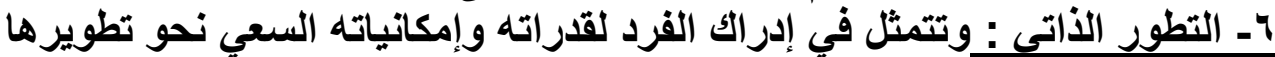

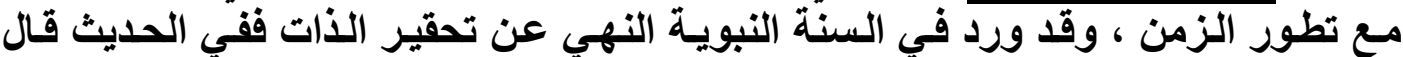

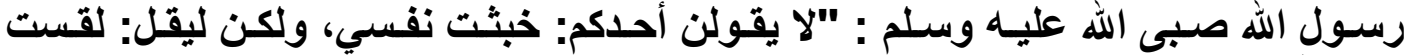

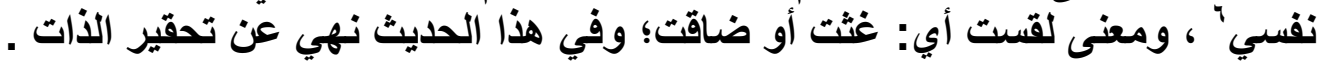

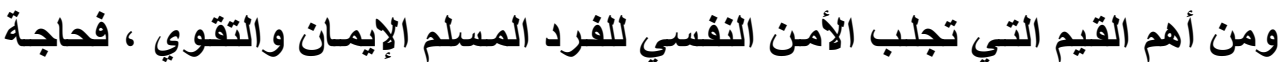

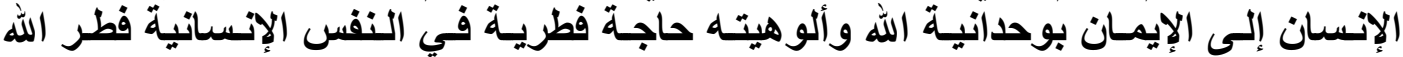

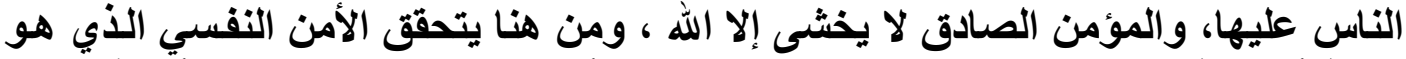

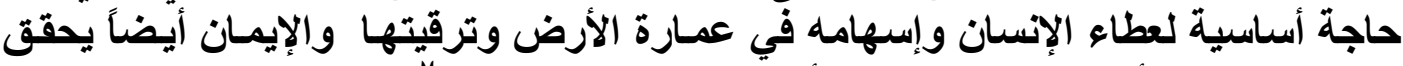

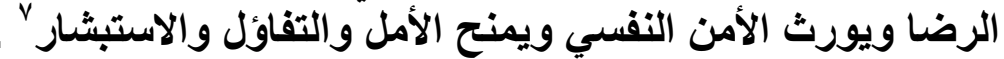

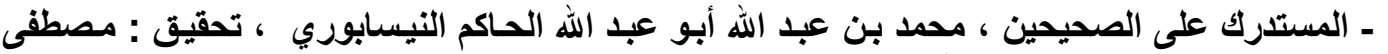

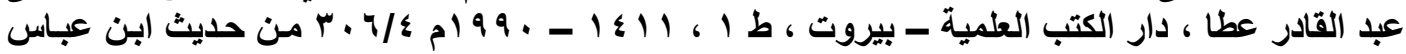

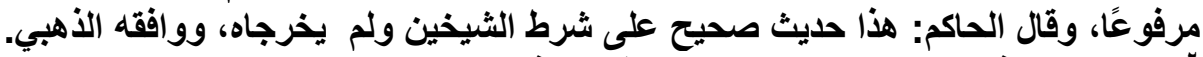

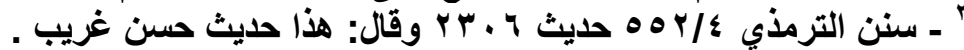

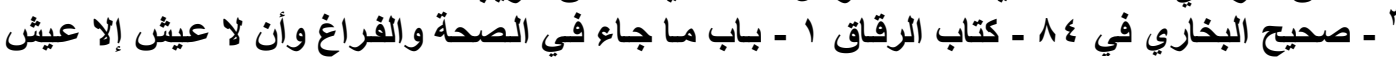

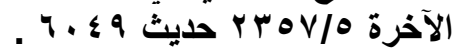

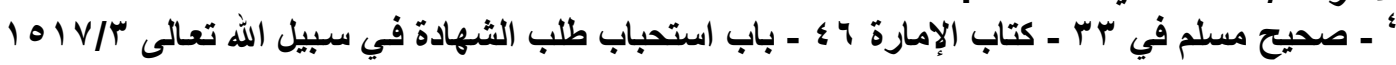

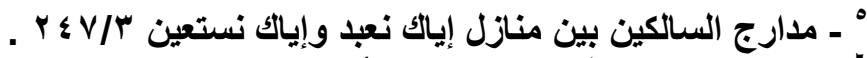

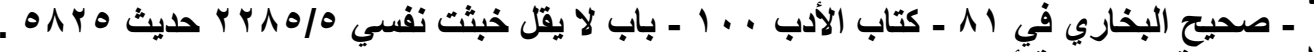

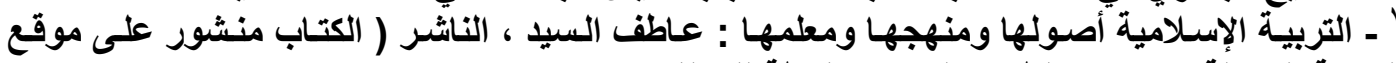

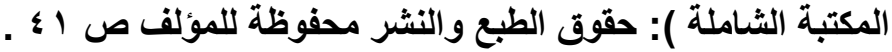


وإذا كـان الإيمـان أصلـه الإيمـان الذي في القلب، فأنسه لابـد فيه من شئئين: الأول

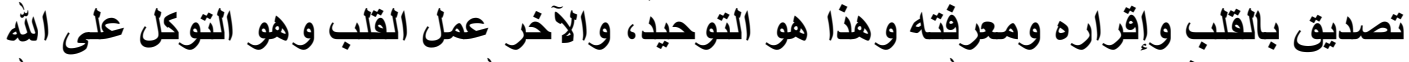

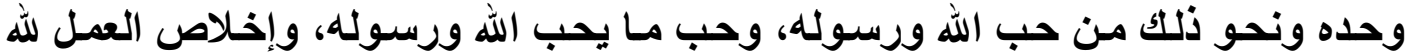

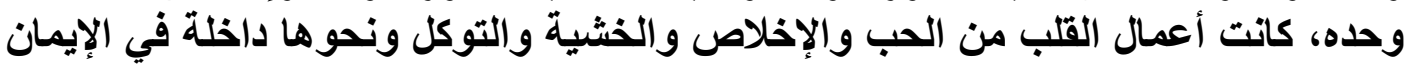

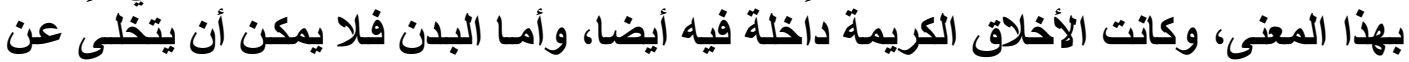

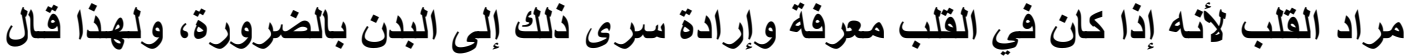

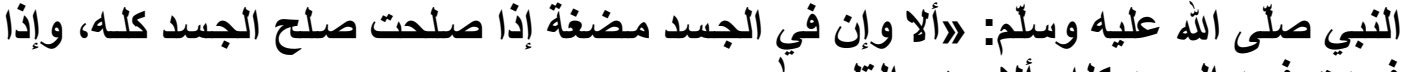

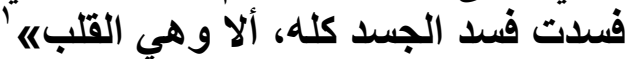

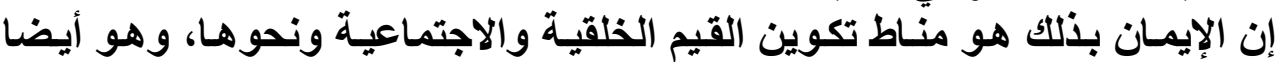

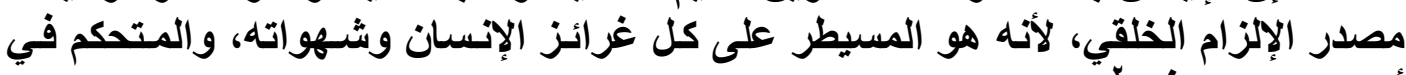

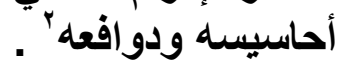

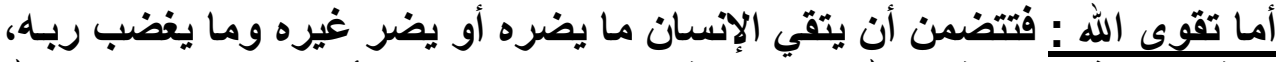

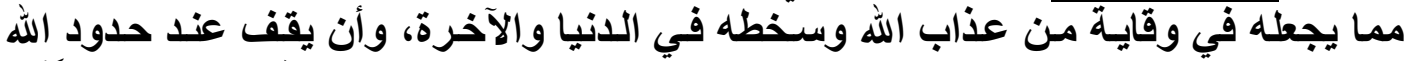

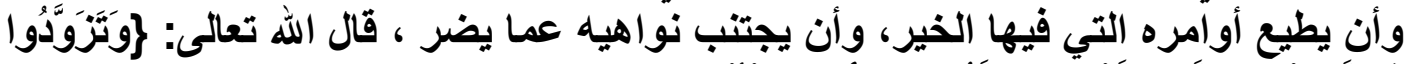

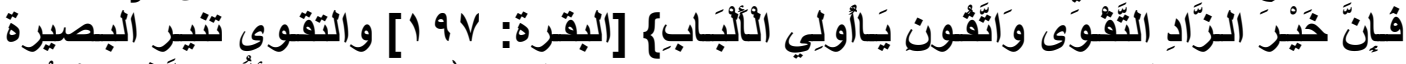

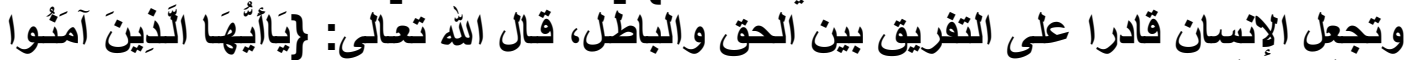

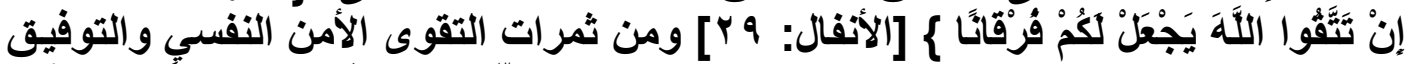

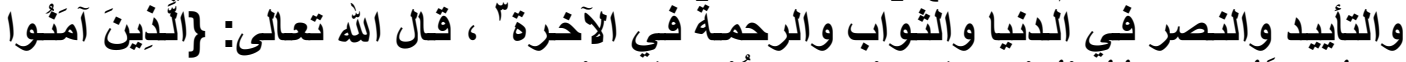

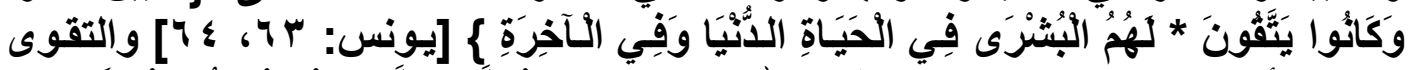

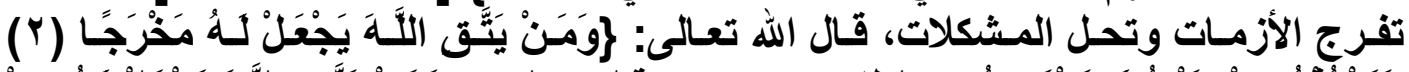

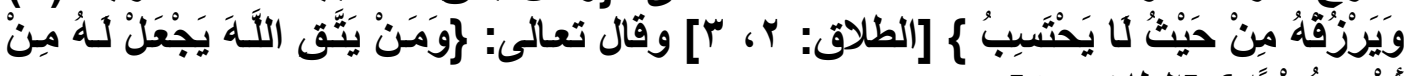

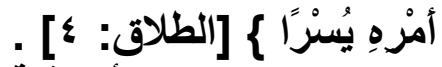

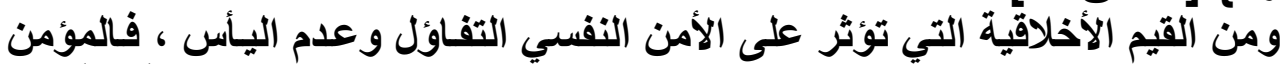

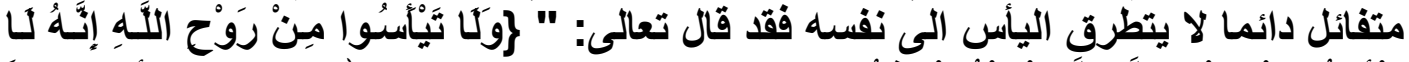

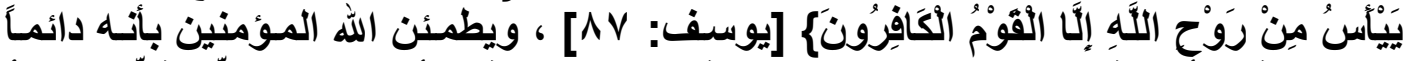

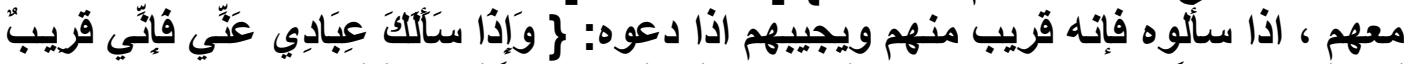

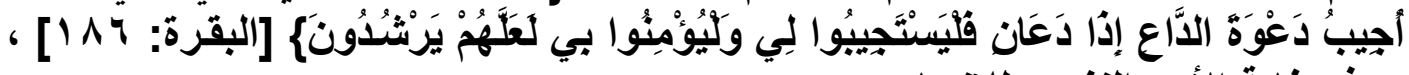

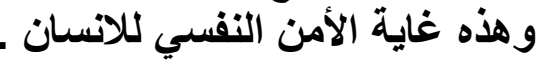
ومما سبق يتضح للباحثة أن الأخلاق تعد صورة المجتمع ، لأنها الضابط و المعيار

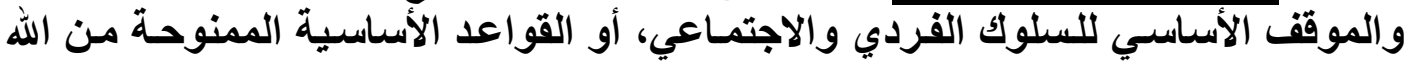

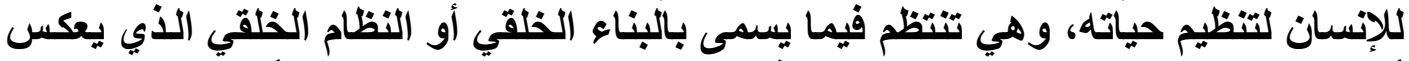

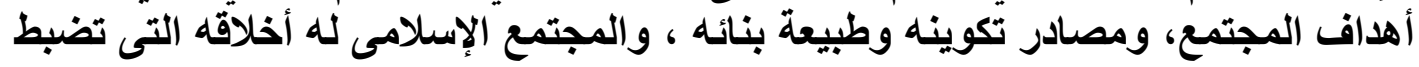

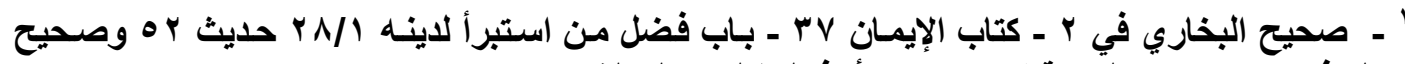

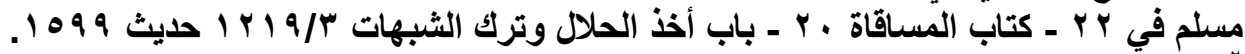

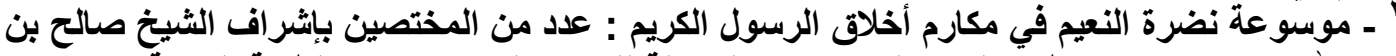

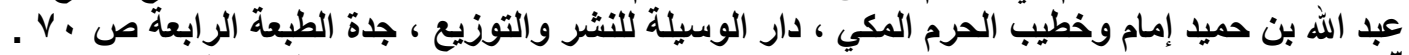

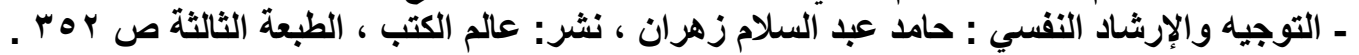




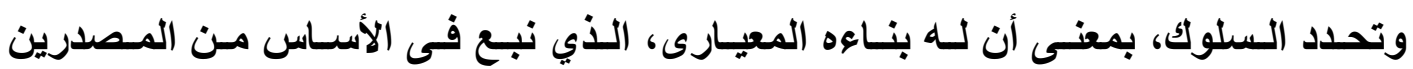

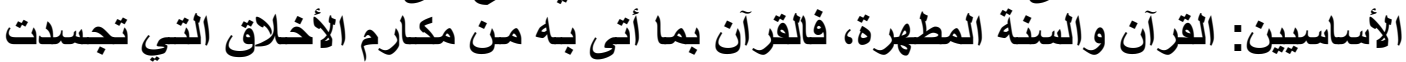

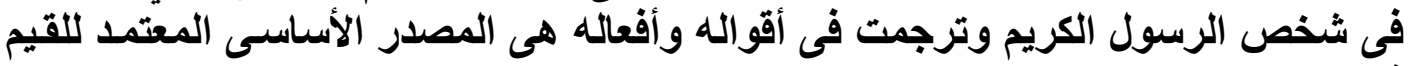
فى المجتمع الإسلامي. 


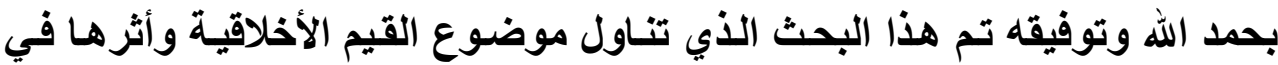
تحقيق الأمن النفسي " دراسة من منظور السنة النبويـة " ، وفيمـا يلـي أهم نتائج البحثة

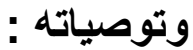
النتائج : وياته :

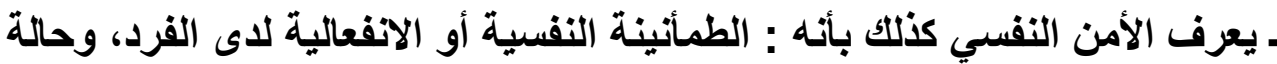

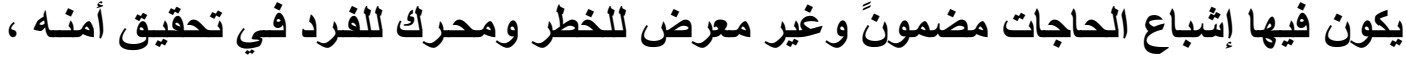

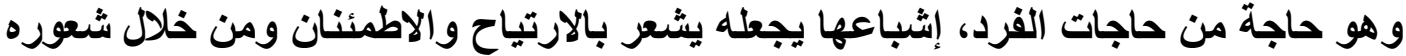

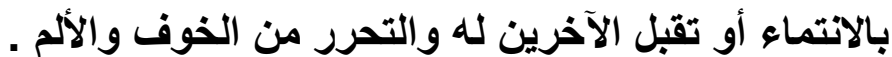

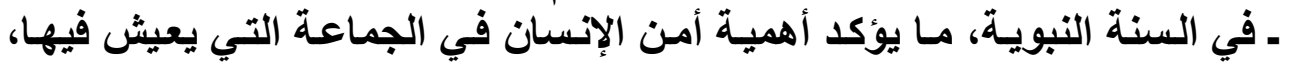

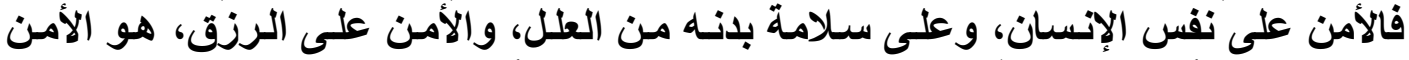

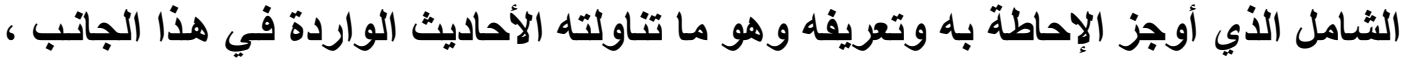

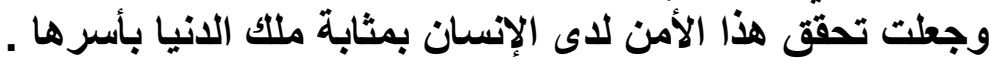

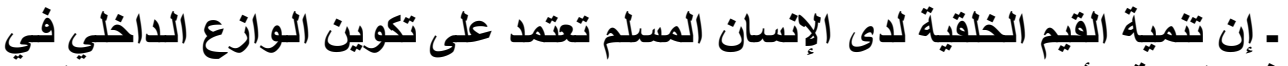

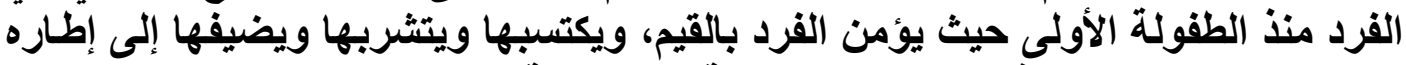

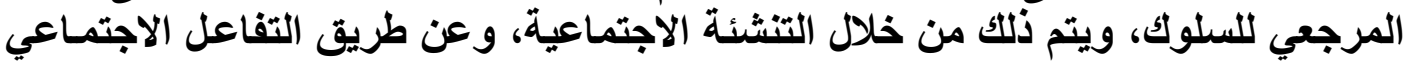

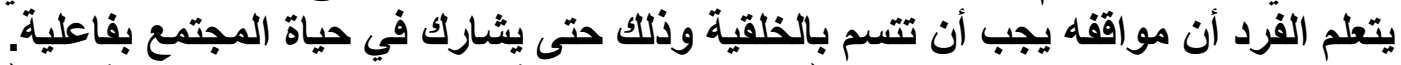

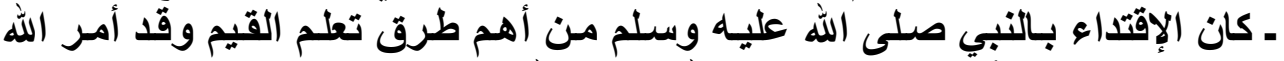

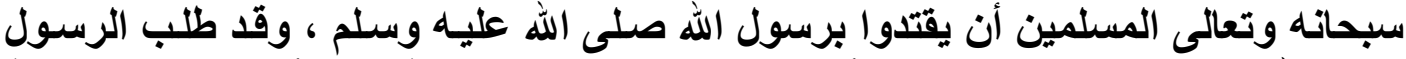

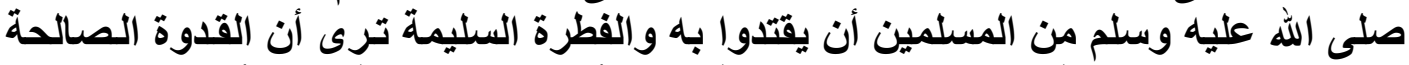

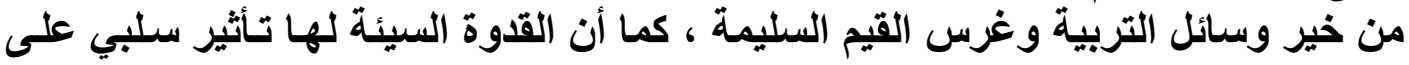

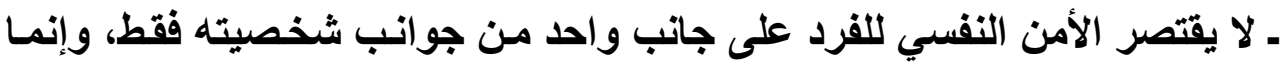

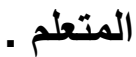

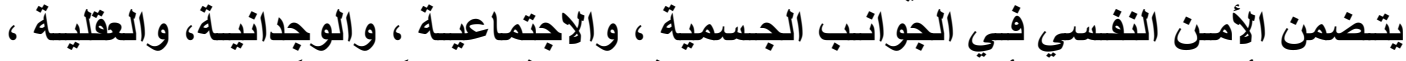

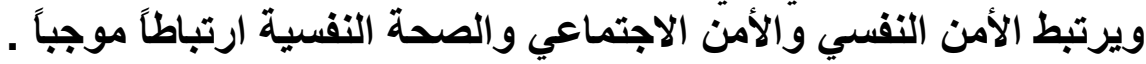

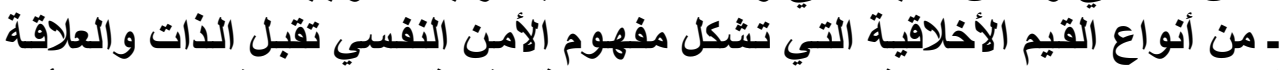

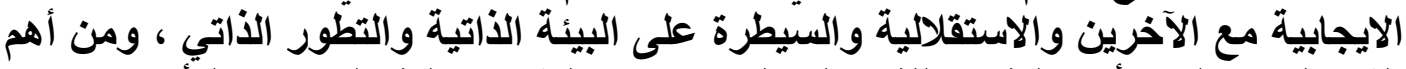

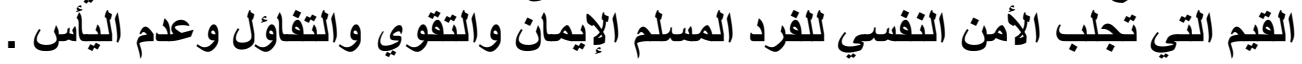

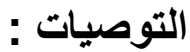

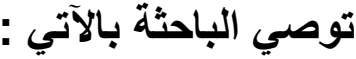

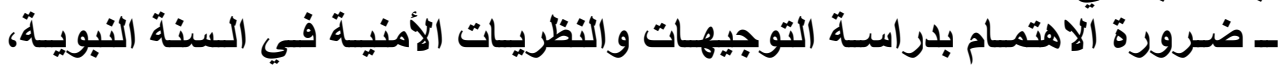
والتأصيل للعلوم المعاصرة . ـ التعاون بين المؤسسات التربوية والاجية الاجتماعية والاعلامية لترسيخ ثقافة الأمن في

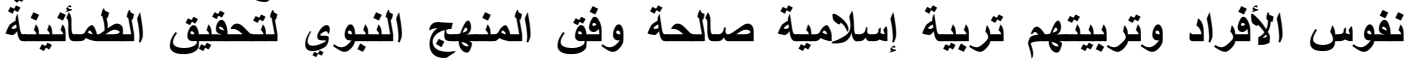

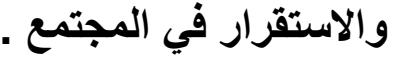

والله ولي التوفيق وعو الهادي إلى سواء السبيل 


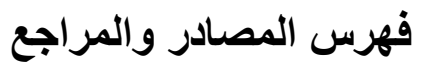

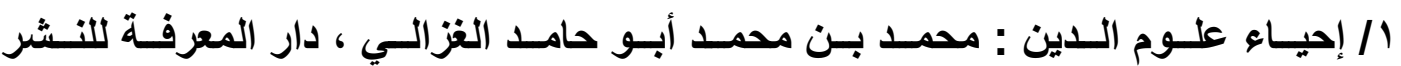
r/ الأدب المفرد : محمد بن إسماعيل أبو عبدالله البخاري ، الناثر : دار البثائر الإسلامية

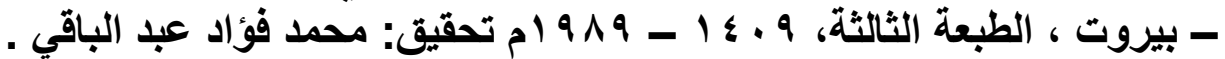

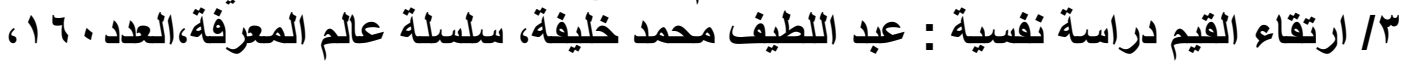

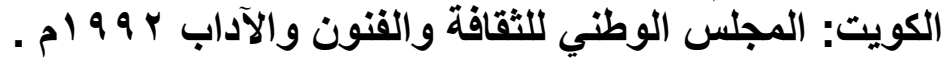

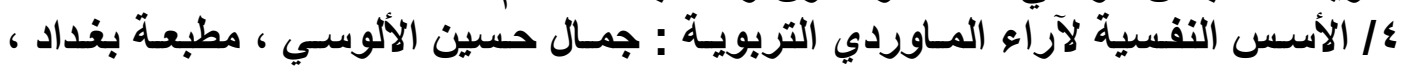
إم/ الإسـلام والأمسن النفسي للإفراد : عبد الرحمن عدس ، مجلـة الأمسن والحيـاة، العدد

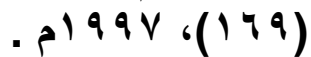

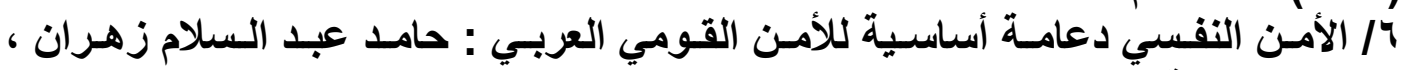

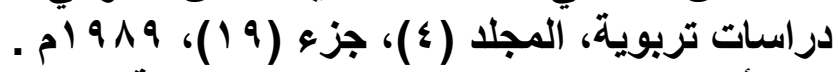

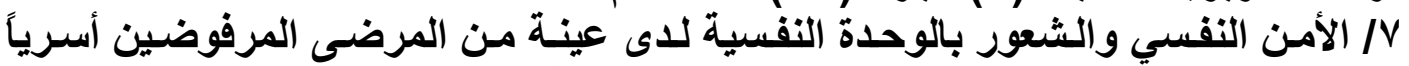

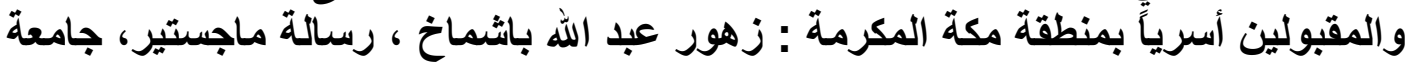

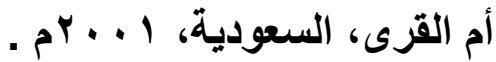

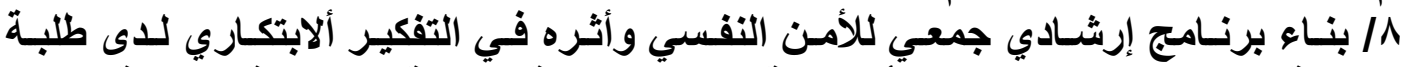

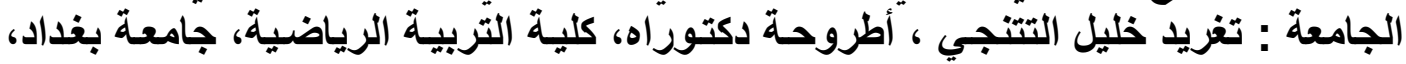

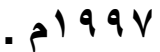

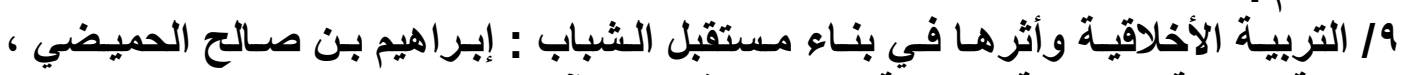

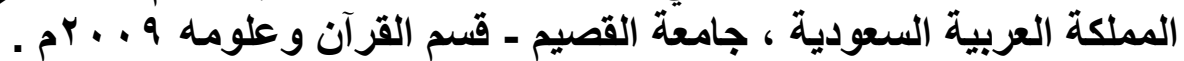

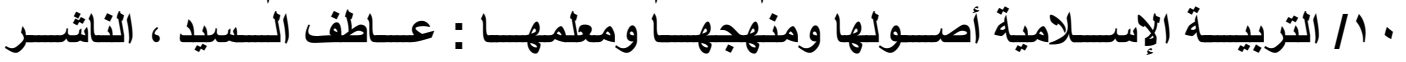

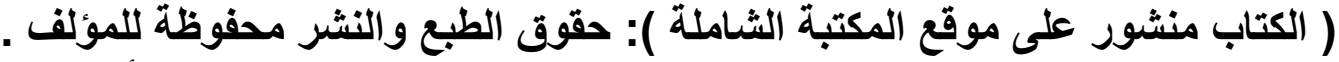

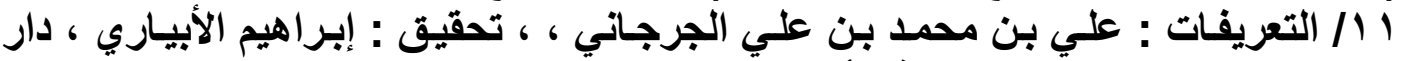

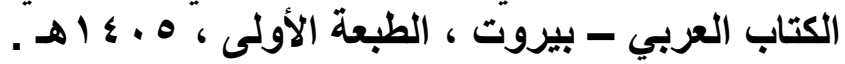
r ال/ التوجية والإرشاد النفسي : حامد عبد السلام زهران ، نشر: دار عالم الكتب ، الطبعة

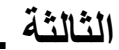
إباء الجامع الصحيح سنن الترمذي : محمد بن عيسى أبو عيسى الترمذي ، الناثنر : دار

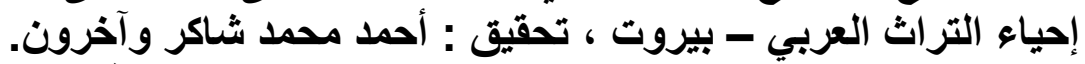

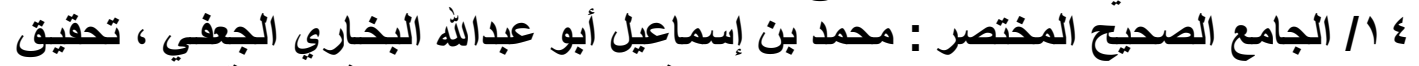

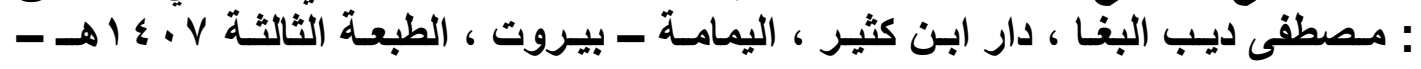

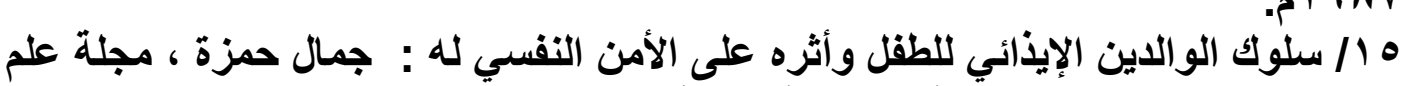

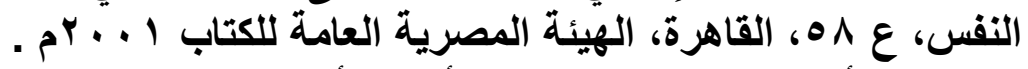

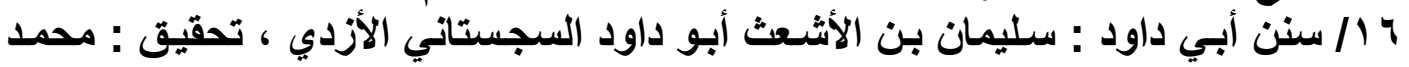

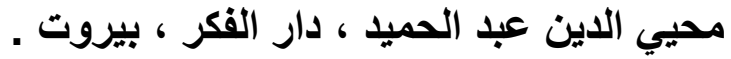




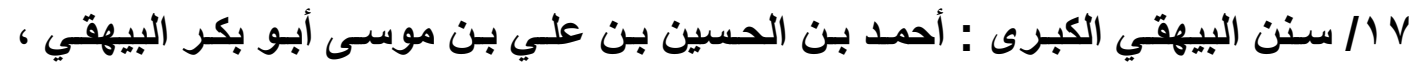

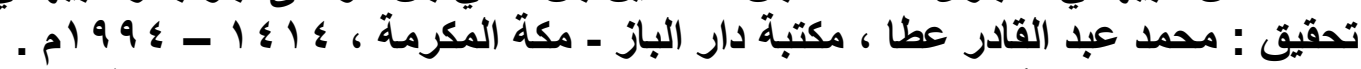

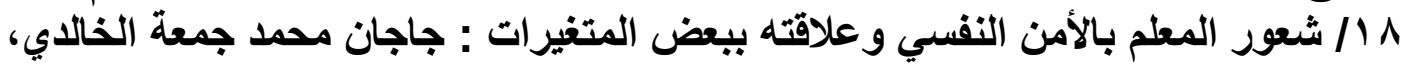

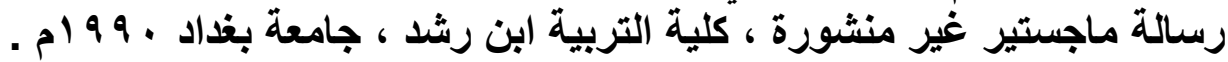

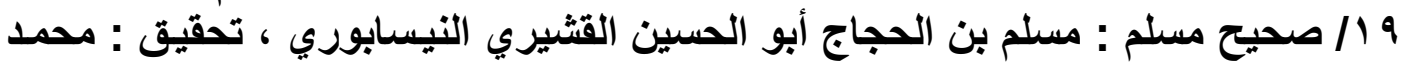

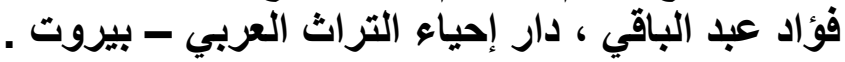

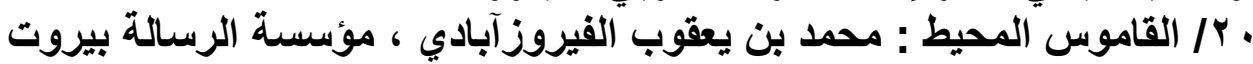

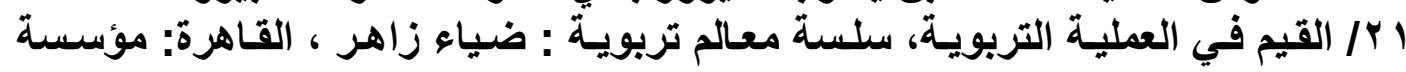

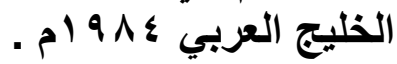

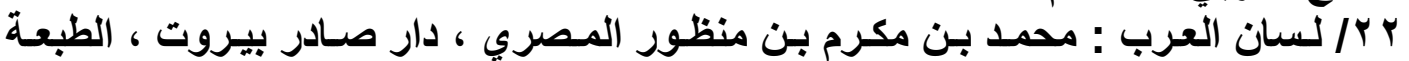

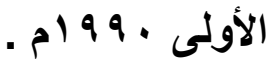

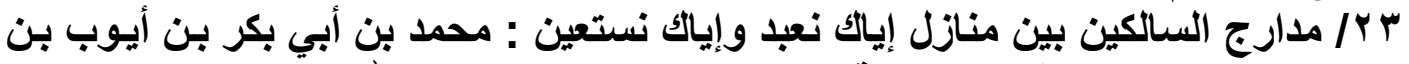

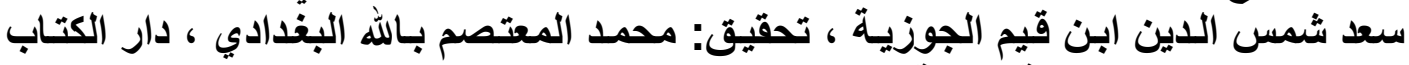

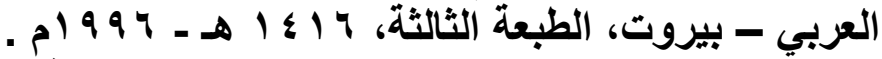

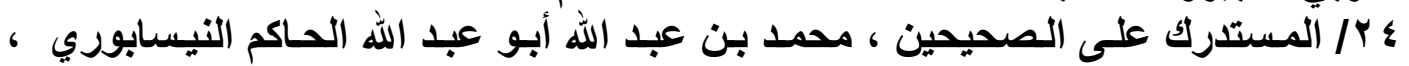

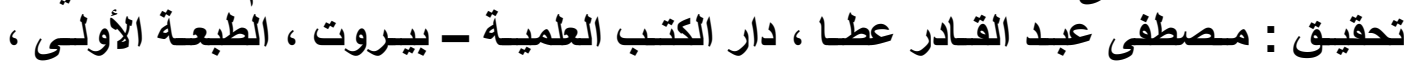
. ه r / مستويات الأمن النفسي لاى الثباب الجامعي ( بحث ميداني حضاري مقارن ) : : علي

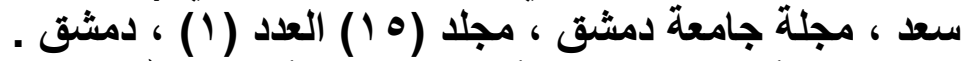

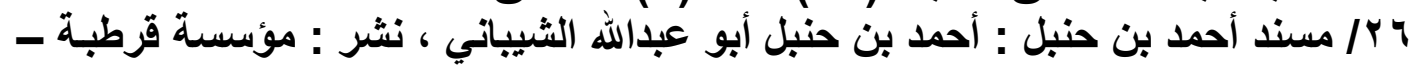
القاهرة .

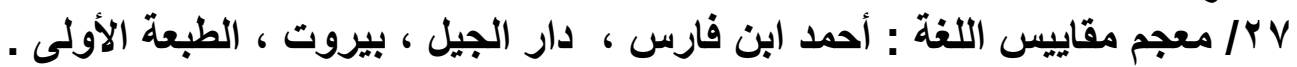

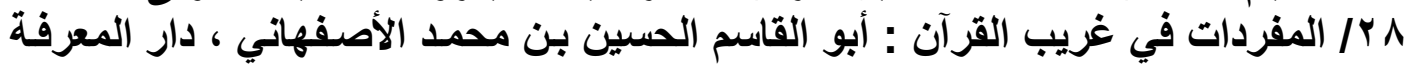

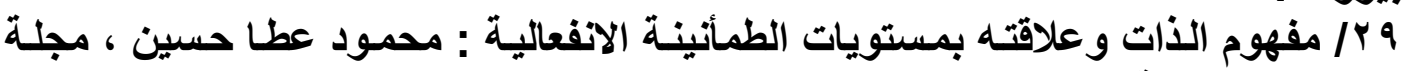

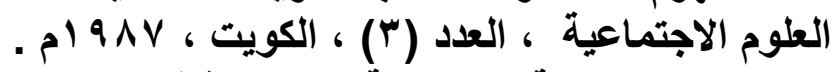

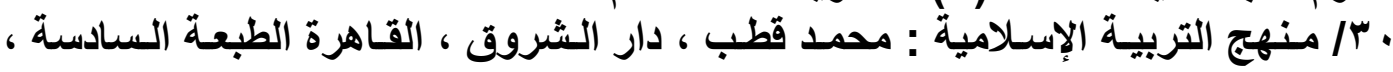

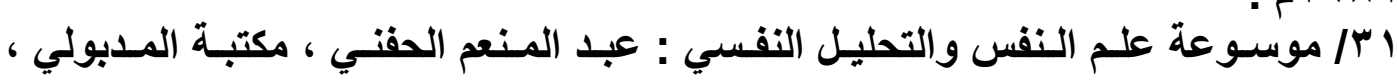

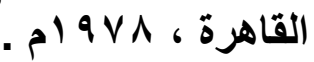

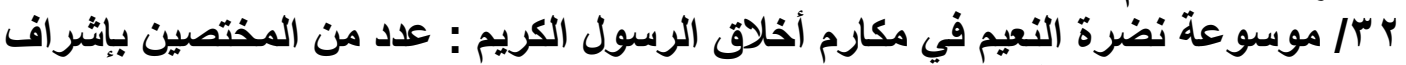

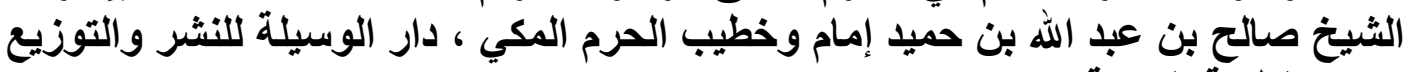

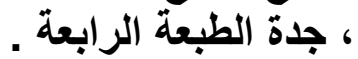
ب آ/ النهاية في غريب الطية الحديث والأثر : المبارك بن محمد بن الأثير الجزري ، دار المكتبة

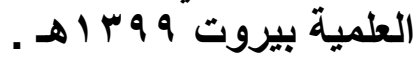

